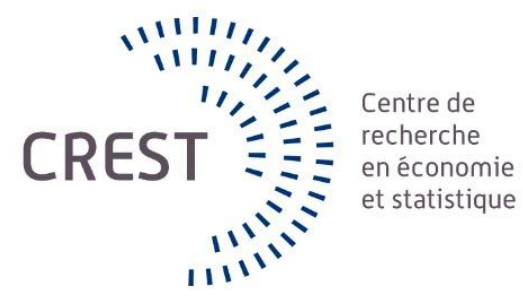

Série des Documents de Travail

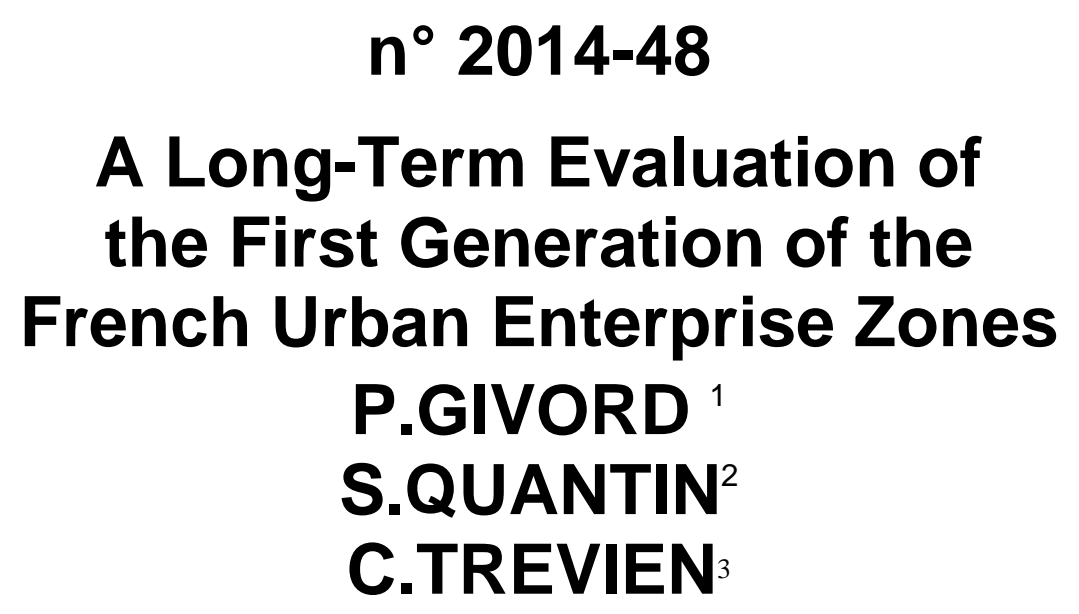

Les documents de travail ne reflètent pas la position du CREST et n'engagent que leurs auteurs. Working papers do not reflect the position of CREST but only the views of the authors.

\footnotetext{
${ }^{1}$ CREST, INSEE.E-mail: Pauline.givord@insee.fr

${ }^{2}$ INSEE.E-mail: simon.quantin@insee.fr

${ }^{3}$ CREST,INSEE, SciencesPo.E-mail: corentin.trevien@insee.fr
} 


\title{
A Long-Term Evaluation of the First Generation of the French Urban Enterprise Zones *
}

\author{
Pauline GIVORD ${ }^{\dagger}$ \\ Simon QUANTIN ${ }^{\ddagger}$ \\ Corentin TREviEN ${ }^{\S}$
}

March 9, 2015

\begin{abstract}
This paper provides new empirical assessment on the long-term efficiency of locally-targeted tax incentives in revitalizing distressed areas, and on the impact on local population. We focus on the first generation of the French "Enterprise Zone" initiative, implemented in 1997 in France. On the opposite to previous results of similar program in France, we observe strong positive impact of EZ on economic activity in the short-run, robust to several identification strategy. However, longrun estimates suggest that this program fails to impulse self-sustaining economic development. After five years, the early positive results are reduced as the increase in business locations is partially offset by more frequent business discontinuations. Besides, the small impact on resident employment and on local services suggests a lack of accurate targeting.
\end{abstract}

Keywords: Enterprise Zones, Local Employment, Propensity Score Matching, Evaluation.

JEL: C23, H71, R5

\footnotetext{
${ }^{*}$ We thank participants of INSEE, Economic Department of Sciences Po and CREST seminars as well as French Applied Microeconomics Conference, European Economic Association congress and European Regional Science Association congress. We thank more specifically Luc Behaghel, Didier Blanchet, Anthony Briant, Xavier D'Haulfœuille, Laurent Gobillon and Thierry Mayer for useful comments and discussions. Any opinions expressed in this paper are those of the author and not of any institution.

${ }^{\dagger}$ INSEE-CREST, pauline.givord@insee.fr

${ }^{\ddagger}$ INSEE, simon.quantin@insee.fr

${ }^{\S}$ INSEE-SciencesPo.-CREST, corentin.trevien@insee.fr
} 


\section{Introduction}

The provision of locally-targeted tax credits and subsidies to kickstart sustainable economic development has become a widely used policy tool. Indeed, the first so-called "Enterprise Zone" programs were implemented in the UK in the 1980s, and others followed in several US states and elsewhere. In France, the EZ ("Zones Franches Urbaines") program first came into existence in 1997. This program grants temporary but remarkably generous tax incentives to small firms which choose to locate in economically distressed areas. The rationale guiding policy makers when opting for an EZ program is quite simple: reductions in tax are meant to offset the numerous disadvantages associated with deprived areas, such as the shortage of a skilled labor force, the lack of public services, a dearth of inputs, and poor market potential. The EZ initiative may stimulate local economic activity, by attracting firms that will employ the locally resident workforce, and may "revitalize" these neighborhoods by improving the local amenities (health services, convenience stores...). The spinoff effects ought to include increased local demand, and greater incentive for other new firms to choose the same location because of agglomeration economies. Once this initial boost had been delivered, the EZ initiative was expected to terminate.

However, as stressed by Neumark and Simpson (2014) in a critical review of the already large economic literature on place-based policies, the theoretical foundations of these policies have not been well established (see also Kline and Moretti 2014). As well, these programs may have potential adverse effects such as inducing firms to hire workers who are already involved in work-based networks, instead of targeting local unemployed people for their hires; and they may have negative externalities on neighboring localities which are often not much better off than the EZ itself. The variety of empirical evaluations of these policies, which mostly focus on their impact on employment, reflects the ambiguity of the theoretical mechanisms. Although most evaluations find no significant increase in employment (see for instance Bondonio and Greenbaum, 2007 or Neumark and Kolko, 2010 for the US enterprise Zones, or Accetturo and de Blasio, 2011 for the Italian "Patti Territoriali"), a significant minority do (see for instance Ham, Swenson, Imrohoroglu, and Song 2011, Busso and Kline 2008). For France, several papers focus on the second wave of the EZ program, implemented in 2002. They obtain a significant but small impact on firm locations and related employment (see for instance Givord, Rathelot, and Sillard, 2013 or Mayer, Mayneris, and Py, 2012). Still, the breadth of the empirical literature on place-based programs notwithstanding, many questions remain unanswered. Neumark and Simpson (2014) identify a research agenda, suggesting several areas where evidence capable of guiding policy is still lacking. Investigating the long-term effect of these programs is the first of them, as one of the main challenges of place-based policy is to generate self-sustaining economic gains. The other open questions include: a more precise identification of "what the effects are" and who gains and who loses from the policy-based question; and "isolating features of policies that make them effective". 
This paper derives from this research agenda. More specifically, we focus on the first wave of French EZ created in 1997, to evaluate whether this initiative was able to yield long-term economic activity. We try to assess whether the program has had a positive impact on the living conditions of the inhabitants of these disadvantaged neighborhoods. More specifically, while most previous related studies focus on overall firm employment, we analyze resident employment separately from non-resident employment. We also focus on firms engaged in providing local services, as one stated objective of the EZ initiative was to give the local population better access to the sort of "basic" services (physicians, convenience stores, independent retailers like bakers, and tradesmen like plumbers...) that are more likely to suffer hardship from being located in distressed urban areas (small market potential in low-income neighborhoods, low accessibility for non-local employees, high rates of criminality).

Interestingly, while we use similar geolocalized data and the same propensity score method as previous empirical evaluations, which focused on the second wave of this initiative, the results we obtain for the first wave of the French EZ initiative are very different from their findings. While Givord, Rathelot, and Sillard (2013) observe very little impact on the number of plants and employment, we observe on the contrary that the first EZ initiative caused these outcomes to respectively double and triple over a five-year period, compared to the baseline level that would have been achieved without tax rebates. These surprising results are robust to an alternative identification strategy relying on a regression discontinuity design method, for the $44 \mathrm{EZ}$ included in the first wave of the program were indeed selected (out of a previously compiled long list of 450 deprived areas) by relying on a discontinuity rule (only the most populated areas were selected).

Apart from this short-term comparison, our results, covering as they do a much longer period (twelve years) than previous studies, highlight the fact that the short-term assessment of the French EZ initiative may differ sharply from the medium and longterm ones. We observe that the number of firms newly located in EZ increases the first year, and stays at a high level for the next four years. But during this period, the pace of firm closures progressively grows and finally overtakes the pace of new firm locations. This suggests that firms that do choose to locate in an EZ may be non-economically viable ones, likely to fail when they are not subsidized anymore. Besides, firms are free to relocate outside the EZ after the end of the program : the tax cuts are granted to a given firm for only five years. Indeed, a significant part of the EZ effect flows from firm relocations, suggesting the presence of a windfall effect. This result challenges the intuition that an EZ can induce a change in the economic spatial equilibrium, by creating a "virtuous circle." And the fact of the matter is that, while the EZ initiative was originally planned to be temporary, its lifespan has been prolonged repeatedly.

Concerning the situation of the inhabitants of these disadvantaged areas, our results suggest that the EZ initiative achieves its objectives, but only on a limited scale. This in turn suggests a lack of clear targeting of the EZ initiative. Overall, the employment level does increase in the EZ thanks to tax cuts: it is 3 times higher than its counterfactual 
level after five years, and a portion of the employees concerned do live in the municipalities including the disadvantaged areas. However, while the EZ initiative explicitly includes a clause favoring local hiring, in practice the share of local residents employed in firms located in EZs tends to decrease over the period. As regards local amenities, we do observe a positive effect on location decisions by firms in the corresponding sector (trade, health or community services), as the number of these firms increases by $50 \%$ after ten years. But this figure is much smaller than the corresponding one for the "footloose" firms of the business services sector (office cleaning, security, IT services...). The number of these firms who do operate locally and may easily leave the areas when tax breaks end, increases by $300 \%$ after ten years thanks to the EZ initiative.

The paper is organized as follows. Section 2 presents the French EZ program, the EZ areas, and estimates of the magnitude of the financial incentives provided by the program. The data are briefly presented in the following Section. Identification issues are discussed in Section 4. Section 5 displays the results and Section 6 concludes.

\section{The French Enterprise Zones}

\subsection{Selection of the Enterprise Zones}

Urban decay has become a main topic of French public debate since the 1980s. A range of policies have been implemented in response to social and economic problems experienced in the deprived outskirts of France's cities. Indeed, the so-called "social fracture" ("fracture sociale") was an important theme of the 1995 presidential campaign, with the social and economic circumstances in deprived urban areas being identified as the main causes. The "stimulus for cities" law ("Pacte de relance de la ville"), passed in 1996 by the newly elected Government, aimed at addressing the issue of urban decay and reducing inequalities between urban neighborhoods.

This law resulted in the implementation of tax cuts for businesses located in those deprived areas. More precisely, this policy instituted a three-tier classification scheme for disadvantaged urban areas. The first tier is known as ZUS ("Deprived Urban Areas"). They correspond to the 757 most deprived areas in France ${ }^{1}$ according to various indicators of socio-economic development (in particular, high concentrations of social housing and high unemployment rates). The second tier, the ZRU ("Urban Renewal Areas"), contains the most disadvantaged ZUS ranked by a global index of their social and economic position. This index takes into account the unemployment rate, the population size, the proportion of unskilled people, the proportion of young people and the potential tax revenue (product of the tax base by the medium tax rate) of the city. It corresponds to the product of the four first indicators divided by the fifth one. 436 ZRU were designated in 1996 2 Finally, the third tier is constituted by ZFU ("Urban En-

\footnotetext{
${ }^{1} 717$ in continental France and 40 ZUS in French overseas departments. 4.73 millions of people lived in ZUS according to 1990 census data.

${ }^{2} 416$ in continental France and 20 in French overseas departments in 1996.
} 
terprise Zones"), hereafter EZ. These zones are chosen in a two-stage process: only the most populous ZRU are eligible, the official threshold being 10,000 inhabitants, and out of that set the most deprived ZRU, as defined by the same global rating, are designated as Enterprise Zones. In 1997, during the first phase of this initiative, 44 areas received the EZ designation, followed by an additional 41 in 2004 and 15 more in 2007.

Figure 1 illustrates, in the case of the Paris metropolitan region, the uneven local distribution of the unemployment rate, as well as the location of some EZ. This region is the wealthiest in France, but the unemployment rate varies markedly amongst municipalities. The inner northeast suburbs of Paris are a site of concentrated economic difficulty. This large sector apart, municipalities characterized by high rates of unemployment are spread throughout the region. The EZ are located in such economically distressed municipalities, but not always. This is explained by the fact that the unemployment rate in some neighborhoods (the relevant geographical level for EZ) may largely exceed the one estimated at the municipality level. Besides, due to the political bargaining involved, hence the need to disperse targeted areas across France, the designation of EZ doesn't rely on a deterministic way on the index indicating the social and economic position. The upshot is that the EZ are uniformly spatially distributed across France, while urban deprived areas are mostly concentrated in a limited number of municipalities.

\subsection{Advantages granted by the EZ policy}

Enterprise Zones offer remarkably generous incentives (deep tax cuts on property, labor and business taxes). They target only small firms (establishments with less than 50 employees, with an additional condition on the volume of sales), whether located in the area prior the introduction of EZ policy or not (see Table 1 and Appendix A for details). Full exemption is granted for a minimum of five years. In comparison to the tax relief available in EZ, the ZRU and ZUS designations provide much shallower tax credits. The ZRU program provides limited tax cuts, for newly created firms only and over a shorter period (one or two years after startup, depending on the tax). Payroll tax exemption applies to all employees in EZ, while it remains limited to newly hired employees in ZRU. Finally, the ZUS program merely allows local authorities to exempt firms from local business taxes, nor is this tax break mandatory.

The first generation EZ were implemented in 1997 and scheduled for five year. As initially planned, the policy ended in 2001: businesses had to locate in a Enterprise Zone before December 31 to benefit from the tax exemptions. However, the EZ policy was reactivated in 2003 and has been kept alive continuously since then. New areas were designated successively in 2004 and 2007, for a total number of $100 \mathrm{EZ}$ today.

The financial incentives depend on the actual financial burden for small firms, and on the structure of their revenues and costs. To assess the actual generosity of this program, we simulate the benefit using individual databases that provide accurate information (see Appendix B). According to these simulations, payroll tax exemptions account for the largest share of tax reductions. In 1997, the median cut in payroll taxes associated 
with EZ was 6,000 euros and this cut accounted for about $15 \%$ of the median wage bill (see Table B.1). This relative advantage was slightly reduced after the introduction of national payroll scheme changes in 2003 but EZ remain attractive. Under the scheme of payroll taxes in use since this date, the median gain for firms from being located in an EZ still accounts for about $12 \%$ of the median labor cost (with an amount of 4,500 euros).

Eligible firms also benefit from a full exemption from corporate income tax, up to a limit that cannot exceed 20,000 euros per year. In practice, a closer look at real data suggests that this exemption is not as appealing as it may seem. Before the implementation of EZ, more than three quarters of small firms did not pay any corporate income tax. For those which did pay a strictly positive corporate income tax, the median amount paid was 3,700 euros (see Table B.2).

\section{Data}

We exploit two exhaustive administrative datasets to gather rich information on firm demography (number of plants) as well as employment (see details in the appendix C).

The French business register (SIRENE) follows all French firms and plants. Every 1 January, it displays the location of each plant, its firm's legal status, its industry and year of creation. This register also tracks plant creations and relocations from 1 January to 31 December each year. It thus enables us to specify whether a new plant location is an actual creation or a relocation of an existing plant. It also allows us to identify when businesses cease activity. Above all, SIRENE locates precisely all plants in continental France. Thus, we can accurately identify which plants have settled in an EZ and those which have not, which is crucial as EZ do not correspond to administrative boundaries (see also Givord, Rathelot, and Sillard 2013). Indeed, using data even at the level of the smallest French administrative subdivision (the municipality, or commune) would have yielded an underestimation of the impact of tax exemptions, because plants which benefit from EZ tax breaks would have been grouped with plants which do not.

The second dataset (DADS) is an exhaustive administrative employer-employee database with information on the workforce of plants. Employment can be measured in various ways at plant level: full-time equivalents over a year, number of employees at any point of time or as of 1 January. We use this latter measure, which is consistent across years and consistent with the French business register. The DADS thus provides a measure of local employment, meaning employment in plants located in the area. Moreover, DADS allows us to split our employment measure into low-skilled, skilled and high-skilled employment, and also into resident and non-resident employment.

These data allow us to probe the long-run effects of Enterprise Zones, as well as temporal delays or extenuations. SIRENE and DADS are available from 1995 to 2007. This means that we observe data at least 2 years before the introduction of the EZ tax 
exemptions and up to 10 years after.

Finally, the 1990 Population Census allows us to measure socio-demographic variables used for the designation of an area as an Enterprise Zone. For this evaluation, the data have been aggregated at the three-tier classification levels presented in section 2: EZ, ZRU and ZUS.

\section{Identification issue and empirical strategy}

\subsection{Identification issue and process of selection to EZ system}

We restrict our estimation sample to the comparison set of non-beneficiary areas (i.e. the control group) to ZRU, which are areas most similar to EZ. Panel data allow us to eliminate the potential fixed effect specific to each area. More precisely, our main variables of interest are (log-) outcome-level differentiated based on data from 1995, meaning two years prior to the introduction of the tax exemptions (the aim of using such a lag is to avoid capturing potential anticipation effects of the measure, for instance).

Time-differentiation is not sufficient to accurately estimate the causal impact of the EZ system. Indeed, the EZ were chosen from among ZRU suffering from multiple economic handicaps that may also have had an impact on the economic perspective. However, the two-step assignment process does provide us with an identification strategy.

First, the eligibility condition based on the size of the areas (in terms of inhabitants estimated in the 1990 population census) ensures that non-EZ areas comparable to EZ in terms of socio-economic development can be found. Indeed, almost all EZ have more than 10,000 inhabitants (see Figure 2) $!^{3}$ This assumption is supported by descriptive statistics on socio-economic characteristics (see Table 2). For each criterion (unemployment rate, percentage of social housing, percentage of young people, foreign people and unskilled people in the area, and potential tax revenue in the municipality in 1996), average figures in small ZRU (meaning those populated by less than 10,000 inhabitants) appear close to the EZ; in some cases they are worse. For instance, the average unemployment rate is $22 \%$ in EZ while it is "only" $18 \%$ in big ZRU but $24 \%$ in small ZRU. The proportion of unskilled people is $43 \%$ in EZ, while it is $36 \%$ (respectively $46 \%$ ) in big (respectively small) ZRU.

Second, as we know and measure the characteristics used in the EZ designation, we can accurately control for differences arising from this selection process. This suggests the choice, common in this literature, of an estimation based on the propensity score method. However, we adapt the estimation to take into account the discontinuity introduced by the eligibility threshold. Moreover, this eligibility condition provides an alternative identification strategy based on regression discontinuity that we will use as a robustness

\footnotetext{
${ }^{3}$ With the exception of four areas: two very small zones that were merged to bigger EZs, and two areas that are just below the threshold, with 9,538 and 9,927 inhabitants, respectively.
} 
check of our results.

\subsection{Estimator based on the propensity score}

\subsubsection{Subclassification on the propensity score and Regression}

In practice, we compare the evolution of outcomes in EZ by using areas that do not benefit from the EZ initiative, but are similar in terms of socio-economic characteristics. More specifically, our main assumption is the standard "conditional independence assumption" (CIA) (or unconfoundedness assumption) which states that, in the absence of the policy, no difference would have been observed in the evolution of outcomes in zones with comparable observable characteristics. As we use outcomes in temporal differences, this method is often named "conditional difference in differences".

As shown by Rosenbaum and Rubin (1983a), if the CIA holds for observables $X$, it also holds for the propensity score $P\left(T_{i}=1 \mid X\right)$ (i.e. the probability of an area being designated as an EZ, conditional on observables). In practice, we use as control variables the indicators formally used for the designation of EZ, but also other indicators that may have an impact on both designation and economic outcomes, namely the proportion of foreigners and executives in the area, as well as the proportion of stable households and the amount of social housing.

However, as our sample size is small, simple propensity-score matching might lead us to compare units with different observable characteristics (as areas with close propensity scores may still have different observable characteristics). To address this issue, we adopt a strategy that combines regression and propensity score methods for the final estimate of the impact of the EZ. More precisely, we define four strata corresponding to the level of the propensity score, and perform a linear regression using observable covariates $X$. As discussed by Imbens and Wooldridge (2009), the linear regression (originally suggested by Rosenbaum and Rubin 1983b) helps to eliminate potential remaining bias and to improve precision. Within each block, the propensity score does not vary much, and covariate distributions are on average similar between both groups. This insures that the regression function will not extrapolate, perhaps erroneously, into regions outside the data range. The estimate of average treatment effect on the treated (ATT) corresponds to the weighted average of these local estimates.

Formally, and using notation posited by Imbens and Wooldridge (2009), we perform the linear regression in each stratum $j$ :

$$
\Delta_{1995} \log \left(Y_{i t}\right)=X_{i} \beta_{j}+\delta_{j} T_{i}+u_{i j}
$$

If we denote $J$ the number of strata (four in our estimates), the final estimate of the impact of the tax subsidies on the EZ $\delta_{A T T}$ corresponds to: 


$$
\hat{\delta}_{A T T}=\sum_{j=1}^{J} \frac{N_{j E Z}}{N_{E Z}} \hat{\delta}_{j}
$$

and an estimate for its variance is:

$$
\hat{V}=\sum_{j=1}^{J}\left(\frac{N_{j E Z}}{N_{E Z}}\right)^{2} \hat{V}_{j}
$$

where $\left(\hat{V}_{j}\right)_{j=1, \ldots, J}$ corresponds to the estimated variances of $\left(\hat{\delta}_{j}\right)_{j=1, \ldots, J}$ (assuming that the residuals for different strata are independently distributed, which is a standard assumption in this kind of method) and $N_{j E Z}$ and $N_{E Z}$ respectively denote the number of EZ in strata $j$ and in the whole sample. We introduce the number of inhabitants of the area as an additional covariate in (1), as an informal test of the assumption of conditional independence of outcome and size. It is never significant.

\subsubsection{Propensity score estimation}

Because of the eligibility condition based on the number of inhabitants in the area, we adapt the estimation of the propensity score to this specific setting. This size condition reinforces the credibility of our identifying assumption (as it ensures that we have control with close characteristics), but it can impact the estimation of the propensity score. Indeed, it leads to a censoring for the observed status (EZ or not) of an area. If some observable characteristics used for the score are correlated with the size of the area (or, to put it differently, if the distribution of observables is not the same in small and large areas as shown in Table 2 for instance), a "naive" estimation of the propensity score may lead to biased estimates of the correlation between observed covariates and the score.

Formally, we can assume that the fact of being selected as an EZ, $T_{i}$, depends on covariates $X$, but an area is selected as an EZ if $T_{i}=1$ and $S_{i}>\underline{S}$. As we wish to evaluate the impact of being selected as an EZ, we are interested in estimating the propensity score $P\left(T_{i}=1, S_{i}>\underline{S} \mid X\right)$, which may be decomposed as $P\left(T_{i}=1 \mid X_{i}, S_{i}>\underline{S}\right) P\left(S_{i}>\underline{S} \mid X\right)$. Under mild assumptions 4 we can estimate both components separately.

In practice, this means that we estimate as a function of the covariates both the probability of being an EZ (restricting the sample to areas with more than 10,000 inhabitants) and the fact of having more than 10,000 inhabitants. The second estimation has no causal interpretation, but corrects for misspecification due to differences in the distributions of the covariates in large and small areas. In both cases, we rely on logistic specifications.

\footnotetext{
${ }^{4}$ Meaning that in the absence of this eligibility condition, the fact of being EZ $T_{i}$ is independent of being a "big" area $D_{i}$ conditional on the characteristics $X$, where the dummy $D_{i}=1_{S_{i}>\underline{S}}$ indicates whether the size is higher than 10,000 inhabitants or not. Indeed one may easily show that the likelihood of the observations $\left(D_{i}, T_{i} D_{i}\right)$ is separable in both components.
} 
These estimations are provided in Table 3 . The first column displays the estimated impacts, for a ZRU with more than 10,000 inhabitants of various socio-economic criteria, on the probability to be included in the EZ program (i.e. $P\left(T_{i}=1 \mid X_{i}, S_{i}>\underline{S}\right)$ ). As expected, this probability is an increasing function of the unemployment rate and the proportion of young and unskilled people, and a decreasing function of the potential tax revenue of the municipality, as it corresponds to the criteria in the selection process. EZ are also characterized by a higher proportion of social housing and foreigners, and a lower proportion of executives and stable households. We now turn to the estimates of the impact of the same range of criteria on the probability for a ZRU to have more than 10,000 inhabitants (i.e. $P\left(S_{i}>\underline{S} \mid X\right)$ ); the results are displayed in the second column. They suggest that the distribution of these variables (in particular, proportion of executives, potential tax revenue and proportion of unskilled people) are not the same in small and in large ZRUs.

Finally, the estimated propensity score for one ZRU corresponds to the product of the two predicted probabilities, given the observed covariates of this area. Figure 3 shows the density of the propensity score for both the treated and control groups. The treated group contains 45 areas, and the control group contains 331 areas. As expected, we observe two distinct modes, meaning that the distributions of the covariates are different in both groups. However, the common support is large, meaning that comparable areas may be found for most EZ.

\subsection{Regression Discontinuity Design}

We also use the eligibility threshold to propose an alternative strategy. Indeed, the probability that a given ZRU will be chosen to benefit from the EZ program increases sharply at the 10,000 inhabitants threshold (see Figure D.1). The design is only "fuzzy," as the EZ selection process is not a deterministic function of population size : numerous large ZRU have not become EZ, and a few small ZRU have become EZ. Our setting is very similar to that of Battistin and Rettore (2008), where endogenous selection occurred amongst a pool of eligible units. One threat to the validity of this approach arises when the selection variable can be manipulated by economic agents in order to be on the "favorable" side of the threshold. In our case, this selection variable was measured in the 1990 population census, meaning five years before the selection process, so manipulation appears very unlikely.

The fuzzy estimator can be obtained using a two-stage-least-square on the linear regression (for details see Imbens and Lemieux 2008), restricting the estimation sample to units in a small neighborhood to the left and right of a threshold $S$, defined with a bandwidth $h$ by $[\underline{S}-h ; \underline{S}+h]$.

Formally, we estimate

$$
\Delta_{1995} \log \left(Y_{i t}\right)=\alpha+\delta T_{i}+\beta\left(S_{i}-\underline{S}\right) 1_{S_{i}>\underline{S}}+\gamma\left(\underline{S}-S_{i}\right) 1_{S_{i}<\underline{S}}+\gamma X_{i}+u_{i}
$$


by two-stage least squares using the indicator $1_{S_{i}>\underline{S}}$ as an excluded instrument.

A common tradeoff has to be made between increasing precision using a large bandwidth at the risk of using non-comparable units, and a small bandwidth that shrinks the estimation sample. In our case the tradeoff is constrained by the initial small sample size : for instance considering the rather narrow window $[9,000 ; 11,000]$ inhabitants left us with only 34 areas (including 5 EZ) that compromise statistical analysis. We have tested several sizes of the window around the threshold and have verified that only the precision is altered by this choice. As is commonly done, we correct for potential dependency in the selection variable by a linear specification. Because of the small sample size, it appears difficult to control for more complex dependence of outcomes on size areas using a polynomial specification of higher order. For the same reason, it is not possible to include variables used in the selection process of EZ, in contrast to a more flexible method such as the propensity score method. For this reason, and also because it makes our results more directly comparable to the results obtained by previous studies that evaluate the (second wave of) the EZ initiatives, we thus keep the propensity score matching method as our main specification.

\section{Results}

\subsection{Short-term effects}

According to our results, Enterprise Zones have a strong impact on economic activity in targeted areas. Figure 4 displays the cumulative impact of the EZ program over time on number of plants and (salaried) employment (detailed results are presented Table E.1 and Table E.2 in Appendix E). Tax exemptions result in a steady rise in the number of firms over the first five years. In 2001, the estimate of the impact of EZs on the time-differentiated log number of plants located in Enterprise Zones is 0.7. This means that the level reached in 2001 is $e^{0.7} \approx 2$ times higher than the level that would have prevailed without the policy. The estimated impact of EZs on salaried employment is similar. From 2001, the number of salaried employees in EZ firms is 3 times higher than its counterfactual level, according to our estimates. More concretely, a back-ofthe-envelope estimate derived from our results suggests that the whole program would have resulted during the first five years in the location of around 11,000 firms employing 50,500 workers. ${ }^{5}$ It is worth stressing that this effect strongly exceeds the findings of previous studies that evaluate the second-generation of the French Enterprise Zones (see Rathelot and Sillard 2008, Givord, Rathelot, and Sillard 2013). We discuss this point in section 6 .

As illustrated by Figures 4 and 5 , our estimates also confirm that prior to the implementation of the EZ program, the trend of economic activity was similar in future EZ and in those zones used as a control group. Indeed, when applying the same estimation method to periods before the introduction of the EZ initiative (corresponding a "placebo"

\footnotetext{
${ }^{5}$ The impact of the EZ in the outcome in level corresponds to $\left(1-e^{-\delta_{t}}\right) Y_{i, t}$.
} 
or "falsification" test), we cannot reject the null hypothesis of a null impact of the EZ before the implementation of tax exemptions in 1997 (see precise estimates in Tables E.1 to E.3 in Appendix D).

\subsection{Long-term effects}

Despite a promising start, several points cast doubt on the ability of the EZ program to impart a long-lasting momentum to economic activity. First, the impact appears to stabilize for both employment and firm location after 2001. This can be explained by the fact that in-zone business locations are now canceled out by relocations outside the EZ, and business closures. Between 1997 and 2001, EZ had a notably higher impact on the creation than on the shutdown of companies with salaried employees. From 2002, the two levels are no longer significantly different (see left panel in Figure 5 and Table E.1. in Appendix E). Interestingly, this realignment coincides with the termination of the program for the firms which entered it in 1997.

Besides, an increasing part of business location is due to relocation. The EZ impact grows between 1997 and 2001, which are respectively the first year out and the fifth year out from the policy implementation. This trend is greater for relocations than for actual creations. More precisely, the estimated impact with respect to plant relocation rises from 0.9 in 1997 to 1.8 in 2001 whereas it only increases from 0.6 to 1 for real creations (see right panel in Figure 5 and Table E.1). To put it another way, in 2001 the number of firm relocations in EZ was 6 times higher than the level that would have prevailed without tax exemptions, while the number of true business creations was 2.7 times higher than its counterfactual level. Firm creations are still predominant among firm locations (at its highest, the share of relocations is $35 \%$ in 2001 while it was $19 \%$ in 1995) ${ }^{6}$

Furthermore, whereas both newly located and existing plants benefit from tax exemptions, the EZ initiative has no impact on employment in existing plants (see Table E.2 in Appendix E). The higher level of employment (compared to the level that would have prevailed in the absence of the EZ policy) appears to be solely due to plants established in EZ after 1995.

Finally, the number of plant locations, and especially relocations, increases sharply in EZ in 2001 but this impact declines in the subsequent year. This suggests that firms do anticipate the end of tax exemptions scheduled for 2001, the terminal date for the policy when it was first announced. Businesses were required to locate in a EZ before December 31, 2001 to benefit from tax exemptions. The return of the conservative party to power in 2002 led to the reactivation of the EZ program after 2003 and firm creation almost recovered to the initial level. This temporal profile suggests that EZ would not have created economic momentum in targeted areas that outlives the (costly) tax incentives.

\footnotetext{
${ }^{6}$ In 1995, 35 firms were created and 8 firms were relocated per EZ on average. Using our estimates for 1997 (resp. 2001), we find that 74 (resp. 92) firms were created and 26 (resp. 48) firms were relocated per EZ.
} 


\subsection{Impact on EZ residents}

The original purpose of EZ was to contribute to urban renewal: the rise in economic activity of firms was viewed as a way to improve the situations of local residents. Concerning this primary objective, our estimates suggest that the EZ program suffers from a lack of accurate targeting. Indeed, low priority outcomes are much more affected by the EZ program than the hiring of residents and the development of local services.

Our data allow us to distinguish between resident employees (i.e. employees who live in the municipality surrounding the EZ and who work in the EZ) with non-resident ones. Indeed, local employment may increase both because more residents are hired, and also because of the hiring of commuters who live further afield. We observe that resident employment does increase at a steady pace between 1997 and 2002 thanks to the EZ initiative (see Table E.3 in Appendix E). However, this pace is slower than the one observed for non-resident employment. Thus, the share of resident employment goes down from $43 \%$ in 1995 before the program to $35 \%$ ten years later (estimates on the causal impact of EZ on this rate are never significant at the usual level). The finding is in line with Gobillon, Magnac, and Selod (2012) who focus on the Paris metropolitan region specifically, and show that the EZ initiative has only a small and non-persistent effect on the unemployment rates of people living in the cities targeted by the EZ program. However, resident employment can be defined at a municipality level, as the place of residence of workers is not as precisely known as firm location. The impact of EZ on resident inhabitants may be consequently even smaller, as we include employees who do not live in the EZ.

Additionally, we decompose the impact of EZ on local employment by skill (see Table E.2. . As low-skilled residents are over-represented in EZ and low-paid workers benefit from higher subsidies, a positive effect on low-skilled workers could be counted as an achievement of the EZ program. We observe that the program does have a positive impact on unskilled workers: after five years, our estimates reveal that the quantity of unskilled employment in the areas is up to 3.2 times the level we should have expected in the absence of the policy. However, these figures are not significantly different from those observed for skilled employment and high skilled employment. Interestingly, we find a positive gap when comparing point estimates for low skilled and higher skilled employment after 2002, that is to say, after the tax cuts were made conditional on local hirings. However, these differences are never statistically significant.

Finally, we break down results at the industry level, in order to evaluate whether or not the EZ program helps to improve local services. Policy makers originally intended to support local amenities, for instance small retail shops such as bakeries, and professional services such as physicians. These correspond to the industrial sectors defined respectively as "trade" and "health, education and community services." According to our results, the EZ initiative has a positive impact on both sectors (see Table E.4). However, the impact is smaller than the overall effect estimated. Indeed the number of trade plants is 1.5 time higher than its counterfactual, whereas the overall effect estimate suggests that the number of plants should have doubled thanks to the EZ program. As 
well, a closer look suggests that the industrial sector most responsive to tax breaks is business services. The impact of EZ is impressive here, as the estimated impact for the number of business service plants in the area peaks at 1.5 in 2001, meaning that the observed level is 4.6 times higher than the counterfactual level. These plants correspond for instance to IT services or office cleaning services, meaning companies whose activities are not necessarily carried out in the neighborhood, but whose legal address can easily be located within the EZ. Such companies may also relocate easily when they no longer benefit from tax exemptions.

\subsection{Regression discontinuities design results and other robustness checks}

We perform several robustness checks. First, as described earlier, we use an alternative empirical strategy using RDD estimates that yield similar results. Second, we check that our control group provides an accurate counterfactual of a situation without local taxes.

As discussed above in section 4, the selection process for EZ also suggests adopting a fuzzy regression discontinuity design approach. Indeed, Figures D.2 and D.3 suggest a discontinuous jump in the number of plants and the employment growth rate at around the 10,000 inhabitants threshold. Table 4 provides estimates for the number of plant: 7 using the fuzzy RDD. The first column corresponds to the method based on propensity score and subclassification, the results of which have already been discussed. The next two columns both correspond to fuzzy RDD estimates. The first one, column (2), is based on a regression on the whole sample correcting for dependence on size, corresponding to model (2). Column (3) is a two-stage least squares regression using a smaller window around the threshold.

The main conclusions remain unchanged. Using RDD estimates leads to the conclusion that there was a non-significant impact of the EZ program for the first two to three years, but the effect is similar and even higher in magnitude subsequently. For instance, in the fifth year after the implementation of the EZ program, its estimated impact on the growth in the number of plants ranges from 0.82 using RDD estimates (using a bandwidth of 3, 000 inhabitants, column (3)) to 0.91 (whole sample of 395 areas, controlling for size effect by a linear specification, column (2)), while it is 0.70 in our main estimations relying on the propensity score method. However, running such RDD estimates entails a loss of precision; this is partly due to the small sample size, as the sample size is limited to 103 areas with $12 \mathrm{EZ}$ when restricting to a close bandwidth.

Finally, we check whether using ZRU as a control group does not lead to underestimating the impact of the EZ policy. The counterfactual situation we want to measure is a total absence of any tax exemptions. However, as firms located in this type of area do benefit from some (limited) tax exemptions, our results may underestimate the total

\footnotetext{
${ }^{7}$ For the sake of clarity, we present the estimates only for the stock of plants, but similar conclusions are obtained for all outcomes. Results available upon request.
} 
effect of EZs on economic activity, if the ZRU exemptions also have a positive impact. We thus estimate the impact of the ZRU program, applying the same methodology as for EZs. ZRUs are now considered as the treated group. We use disadvantaged urban areas that do not benefit from tax breaks as a control group (i.e. ZUS, the first tier of French urban policy, see section 2). According to our estimates, the tax exemptions provided by the ZRU program are inefficient at fostering economic activity (Table 4, column (4)). The evolutions of the stock of plants in ZRUs are never significantly different from the case in ZUS over the whole 12-year period 8 The ZRU program thus has no significant impact on economic activity, and we may be confident that our results do not underestimate the impact of the EZ initiative. Indeed, compared to EZ, ZRU provide much less generous tax breaks to firms, which moreover apply only to new firms (corporate and local business taxes) or new hires (payroll tax). Recent studies suggest that this specific tax scheme is less likely to attract firms. Duranton, Gobillon, and Overman (2010) find no impact of local taxation on non-residential property, on entry by English manufacturing establishments, and Rathelot and Sillard (2008) find significant but negligible impact for French firms.

\section{Discussion and conclusion}

All in all, our results provide new evidence on the efficiency of the place-based program. The overall assessments are mixed, however. To the question "can such a program attract firms into disadvantaged areas," the answer is clearly yes. French firms appear to be strongly reactive to tax breaks proposed by the EZ initiative. The change in stock of firms and local employment are impressive. Five years out from the introduction of the policy, the number of firms doubles compared to the level that would have prevailed without the tax exemptions. On the resident population, the consequences are also positive if not as impressive. We observe a sharp increase in resident and unskilled employment, as well as a clear but weaker rise in industries that provide local services.

However, analysis of the long term impacts mitigates these positive results. Indeed, the initial goal of the EZ policy was not to subsidize local economies endlessly. The first financial impulse was expected to create self-sustaining economic activity, and was thus planned to be temporary. Gauged in this light, the EZ initiative is less successful. After the first five-year period of tax exemptions, the flow of new firms, while still steady, does not lead to an increase in employment: the reason is a higher firm closure rate (or relocation of these firms outsize the areas). In other words, once firms cease to benefit from the tax rebates, they appear to be replaced by new firms which enter the program

\footnotetext{
${ }^{8}$ We observe a small impact on employment in 2005 and 2006, and on firm creations in 2007 (the results are not reported here). This may reflect the fact that some ZRU became EZ in 2004 and 2007. Givord, Rathelot, and Sillard (2013) exhibit a significant impact (but much smaller than for the first wave) of the policy on employment and business demography. As our control group includes some treated areas, it might be "contaminated": our main results could have been underestimated for the very end of the period. We have checked that we obtain similar conclusions when excluding areas selected for the second and third waves of Enterprise Zones from the control group (the results not reported here).
} 
for the first time and can thus benefit from full tax exemption. Indeed, the program was eventually restarted in 2003, meaning that the stabilization in employment level and firm stock observed since this date has been achieved at substantial cost. The brief attempt to halt the program in 2002 results in a significant decrease of new firm location for this year, highlighting the fact that the economic attractiveness of EZ remains largely dependent on tax rebates. Besides, as already noted by previous research on the French EZ, a large part of the inflow of new firms is due to relocation. Subventions do not create genuine new economic activity, and may have negative externalities on the not-so-advantaged neighborhoods close to the EZs, as observed by Givord, Rathelot, and Sillard (2013). Another drawback of the program may lie in its lack of clear targeting. The program has certainly achieved one of its main objectives, that of increasing resident employment and revitalizing the neighborhoods. But the impact appears relatively modest compared to the overall cost of the program (estimated at 300 million euros in 2001 according to an official report by the French Parliament). Besides, Gregoir and Maury (2012) for instance observe a negative impact on house prices in some French EZs of the second wave, which they interpret as a negative signaling effect of EZ status on the population.

Many questions still remain open, about why and where the EZ work. The optimal settings of such a place-based policy need to be evaluated, for EZ programs may propose a wide range of services, tax rebates and subsidies on certain inputs. Recent papers emphasize strong discrepancies linked to the variety of tax cuts (Lynch and Zax 2008), the services provided (Bondonio and Greenbaum 2007), the manner in which the zone is managed (Neumark and Kolko 2010), or the industrial sector in which firm is operating (Hanson and Rohlin 2011, Burnes, Neumark, and White 2012). For France, Briant, Lafourcade, and Schmutz (2012) highlight the importance of geographic context in the success of the second wave of EZ.

The mixed success of French place-based policy also raises some questions. In the short run, the impact of the first wave of the EZ was much higher than that obtained in the second wave by Givord, Rathelot, and Sillard (2013) with similar data and close identification strategy (see also Mayer, Mayneris, and Py 2012). Several explanations can be adduced to explain the apparent decline in the attractiveness of EZ. First, a large program of payroll tax cuts has been implemented on a national scale and has reduced the tax gap between EZs and the rest of the country. Second, after 2003 the subsidies were more strictly contingent on hiring local workers. This so-called local employment stipulation ("clause d'emploi local" in French) was already in effect between 1997 and 2001, but there is evidence to suggest that it was not strictly enforced (see Appendix A). Real or supposed difficulties in hiring adequately skilled workers from among the population of the area may have discouraged new firms from locating there $9^{9}$ Finally, there are grounds for thinking that the number of plants that choose to relocate within an EZ is bounded, either because of limited space, or because of a competition with the

\footnotetext{
${ }^{9}$ In 2008, according to a qualitative survey in the EZs, companies in these zones declare major difficulties in hiring employees inside the area (and minor difficulties in hiring outside the area), as reported in Givord, Rathelot, and Sillard (2013).
} 
second wave of EZ to attract plants that are likely to locate in deprived urban areas. A more complete analysis of these issues in the future may supply useful elements about the optimal settings of such a place-based policy. 


\section{References}

Accetturo, A., and G. De Blasio (2011): "Policies for local development: an evaluation of Italy's \&quot;Patti Territoriali\&quot;", Temi di discussione (Economic working papers) 789, Bank of Italy, Economic Research and International Relations Area.

Battistin, E., And E. Rettore (2008): "Ineligibles and eligible non-participants as a double comparison group in regression-discontinuity designs," Journal of Econometrics, 142(2), 715-730.

Bondonio, D., and R. T. Greenbaum (2007): "Do Local Taxes Incentives Affect Economic Growth? What Mean Impacts Miss in the Analysis of Enterprise Zones Policies," Regional Science and Urban Economics, 37, 121-136.

Briant, A., M. Lafourcade, and B. Schmutz (2012): "Can Tax Breaks Beat Geography? Lessons from the French Enterprise Zone Experience," PSE Working Papers halshs-00695225, HAL.

Burnes, D., D. Neumark, and M. J. White (2012): "Fiscal Zoning, Sales Taxes, and Employment: Do Higher Sales Taxes Lead to More Jobs in Retailing and Fewer Jobs in Manufacturing?," IZA Discussion Papers 6383, Institute for the Study of Labor (IZA).

Busso, M., And P. Kline (2008): "Do Local Economic Development Programs Work? Evidence from the Federal Empowerment Zone Program," Cowles Foundation Discussion Paper 1638.

Duranton, G., L. Gobillon, and H. G. Overman (2010): "Assessing the Effects of Local Taxation using Microgeographic Data," Working Papers 2010-47, Centre de Recherche en Economie et Statistique.

Givord, P., R. Rathelot, and P. Sillard (2013): "Place-based tax exemptions and displacement effects: An evaluation of the Zones Franches Urbaines program," Regional Science and Urban Economics, 43(1), 151-163.

Gobillon, L., T. Magnac, and H. Selod (2012): "Do unemployed workers benefit from enterprise zones? The French experience," Journal of Public Economics, 96(910), 881-892.

Gregoir, S., and T.-P. Maury (2012): "Quel a été l'effet de l'instauration de Zones Franches Urbaines sur les marchés immobiliers locaux ? Le cas de la Seine-SaintDenis.," Position paper, EDHEC.

Ham, J. C., C. Swenson, A. Imrohoroglu, and H. Song (2011): "Government programs can improve local labor markets: Evidence from State Enterprise Zones, Federal Empowerment Zones and Federal Enterprise Community," Journal of Public Economics, 95(7), 779-797. 
Hanson, A., And S. Rohlin (2011): "The Effect of Location-Based Tax Incentives on Establishment Location and Employment across Industry Sectors," Public Finance Review, 39(2), 195-225.

Imbens, G. W., And T. Lemieux (2008): "Regression discontinuity designs: A guide to practice," Journal of Econometrics, 142(2), 615-635.

Imbens, G. W., And J. M. Wooldridge (2009): "Recent Developments in the Econometrics of Program Evaluation," Journal of Economic Literature, 47(1), 5-86.

Kline, P., and E. Moretti (2014): "People, Places, and Public Policy: Some Simple Welfare Economics of Local Economic Development Programs," Annual Review of Economics, 6(1), 629-662.

Lynch, D., AND J. Zax (2008): "Incidence and substitution in Enterprise Zone Programs: The case of Colorado," mimeo.

Mayer, T., F. Mayneris, and L. Py (2012): "The Impact of Urban Enterprise Zones on Establishments' Location Decisions: Evidence from French ZFUs," CEPR Discussion Papers 9074, C.E.P.R. Discussion Papers.

Neumark, D., And J. Kolko (2010): "Do enterprise zones create jobs? Evidence from California's enterprise zone program," Journal of Urban Economics, 68(1), 1-19.

Neumark, D., and H. Simpson (2014): "Place-Based Policies," NBER Working Papers 20049, National Bureau of Economic Research, Inc.

Rathelot, R., and P. Sillard (2008): "The Importance of Local Corporate Taxes in Business Location Decisions: Evidence From French Micro Data," Economic Journal, 118(527), 499-514.

Rosenbaum, P., and D. Rubin (1983a): "The Central Role of the Propensity Score in Observational Studies for Causal Effects," Biometrika, 70, 41-55.

Rosenbaum, P. R., and D. B. Rubin (1983b): "Assessing Sensitivity to an Unobserved Binary Covariate in an Observational Study with Binary Outcome," Journal of the Royal Statistical Society. Series B (Methodological), 45(2), pp. 212-218. 


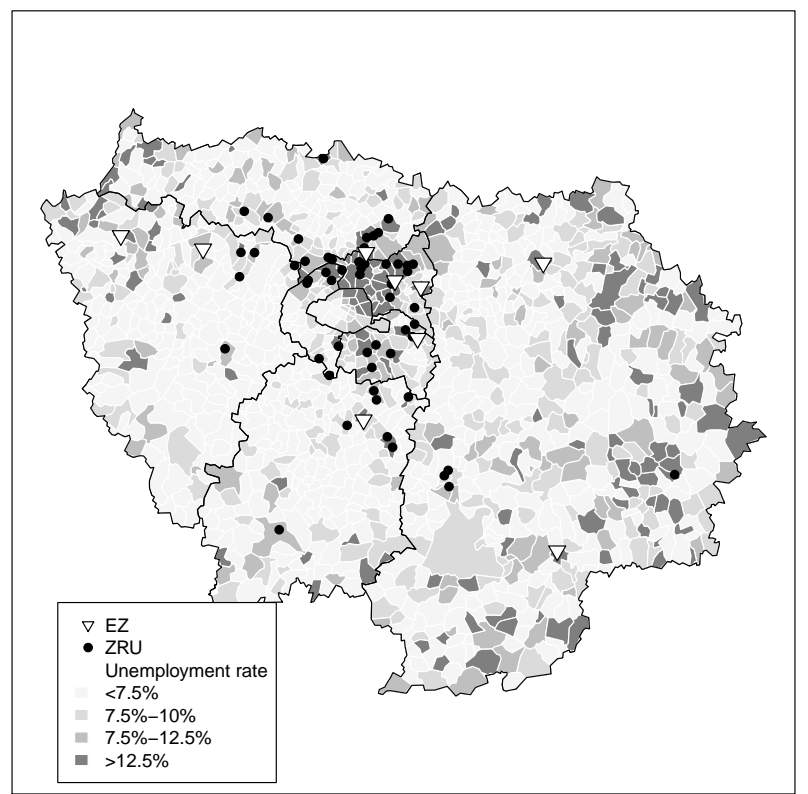

Figure 1: EZ location and unemployment rate in 1990 in the Paris metropolitan region.

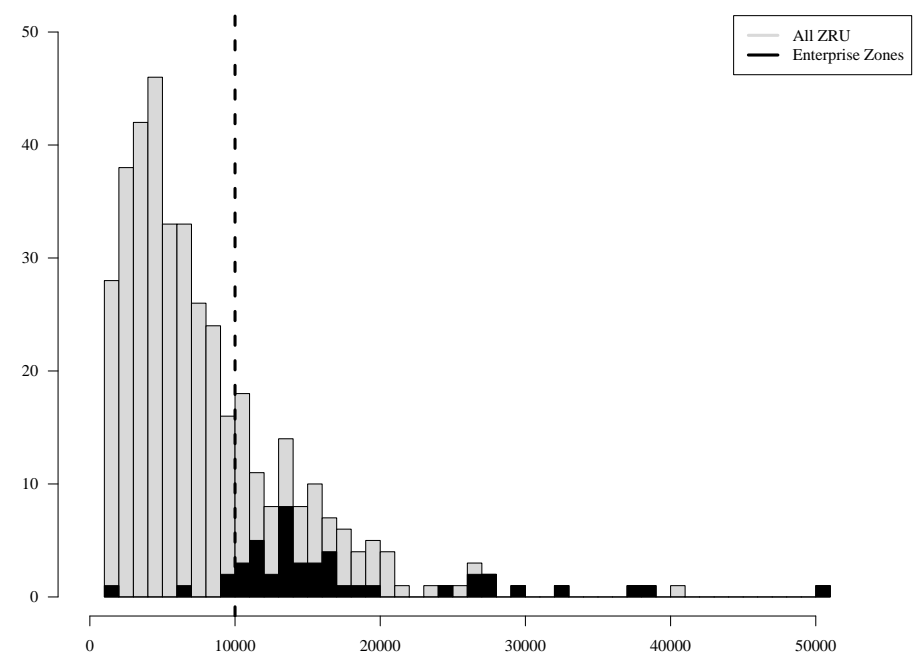

Figure 2: Distribution of EZs and ZRUs according to the number of inhabitants. 


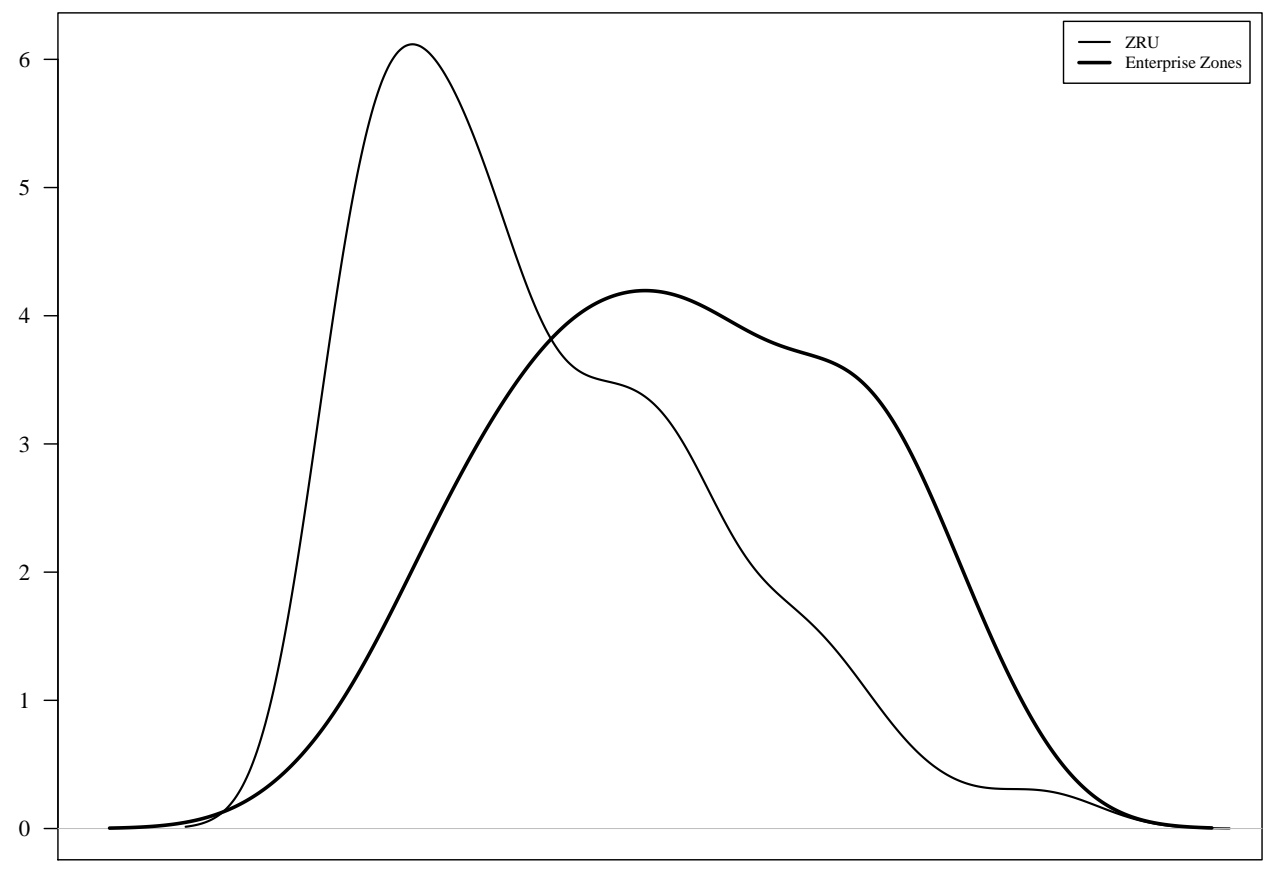

Figure 3: Score density for the treated and control groups
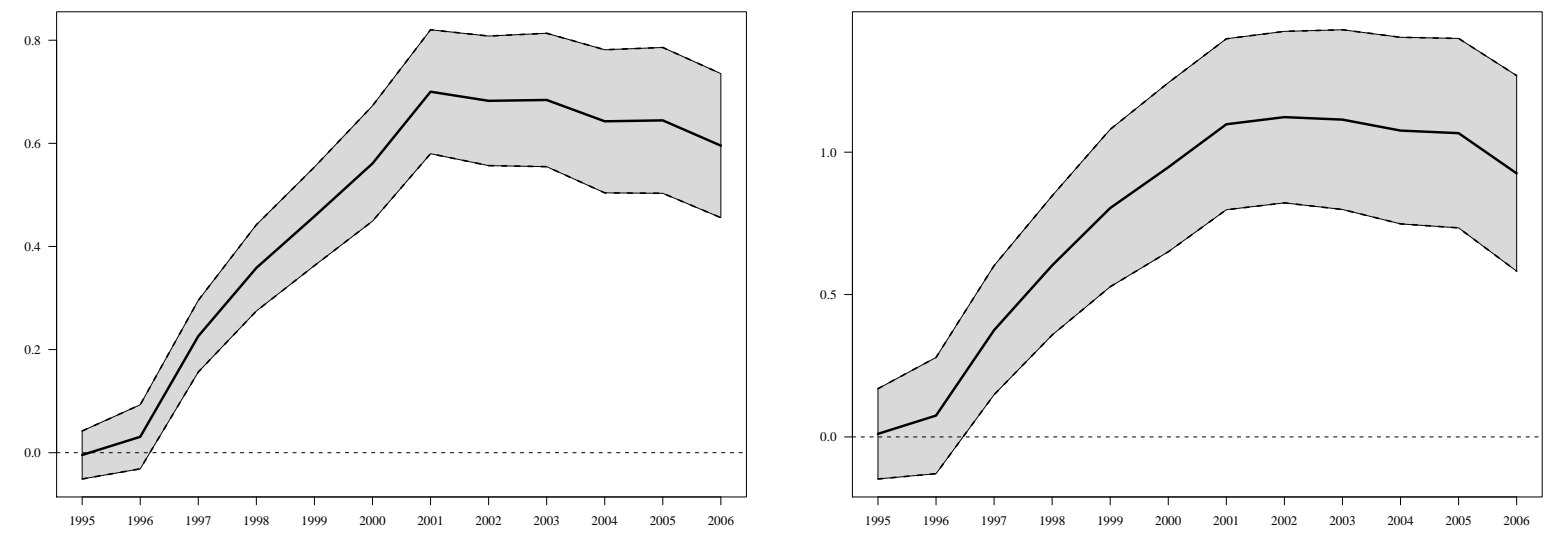

Figure 4: Impact of EZs on the (log) stock of plants and (log) employment. 

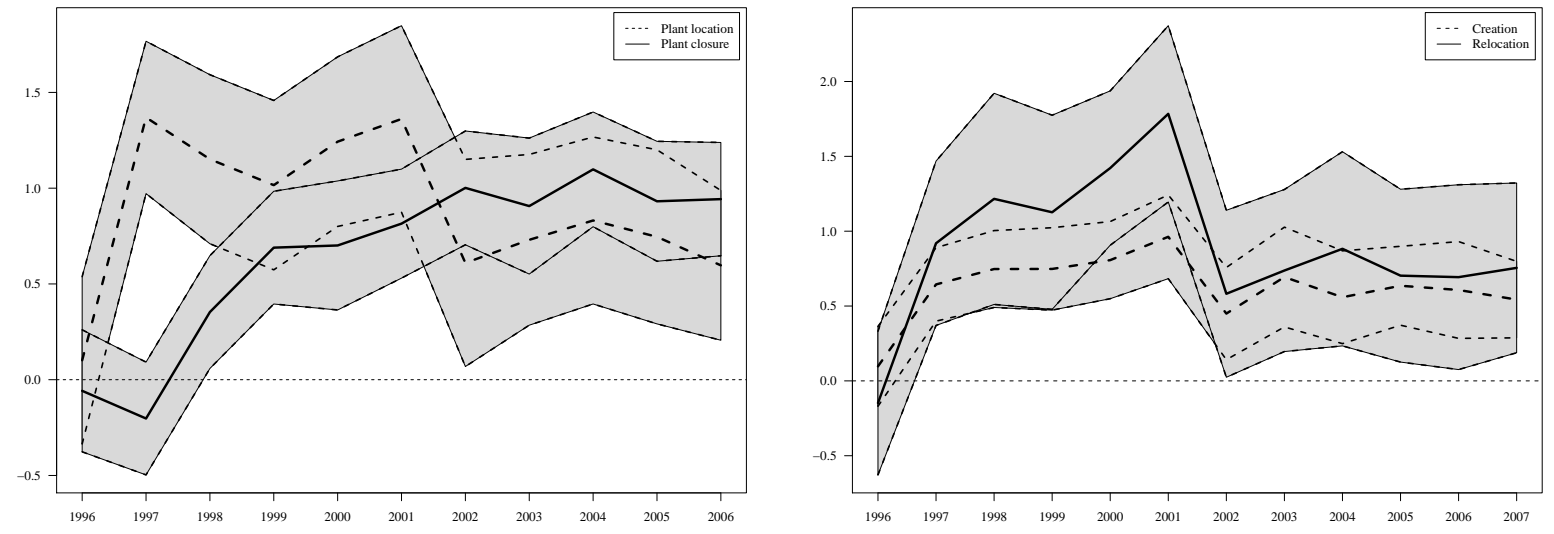

Figure 5: Impact of EZs on the (log) number of plant location and closure (left panel) and plant relocations and creations (right panel). 
Table 1: French Enterprise Zone Tax Cuts

\begin{tabular}{l|l|l}
\hline & ZRU (1996-2004) & ZFU (1996-2001) \\
& & \\
\hline
\end{tabular}

\section{Payroll tax exemptions}

\begin{tabular}{|c|c|c|}
\hline Plant eligibility & & 0 employees \\
\hline \multirow[t]{2}{*}{ Employee eligibility } & new hires & all employees \\
\hline & \multicolumn{2}{|c|}{$\begin{array}{l}\text { open-ended contracts } \\
\text { fixed-term employment contract of more } 12 \text { months }\end{array}$} \\
\hline Exemption & \multicolumn{2}{|c|}{ fraction of salary $\leq 1.5$ times the minimum wage } \\
\hline Duration & 1 year & 5 years \\
\hline
\end{tabular}

\section{Corporate income tax exemptions}

\begin{tabular}{l|l|l}
\hline Eligibility & $\begin{array}{l}\text { newly created } \\
\text { (only in manufacturing, trade or craft in- } \\
\text { dustry) }\end{array}$ & all (created, existing, relocating) \\
\hline Exemption & $\begin{array}{l}100 \% \text { the first 2 years, and decreasing the } \\
\text { next 3 years }\end{array}$ & $100 \%$ during 5 years \\
\hline
\end{tabular}

Local business tax exemptions

\begin{tabular}{l|l|l}
\hline Eligibility & $\begin{array}{l}\text { newly created } \\
\text { with up to 150 employees }\end{array}$ & $\begin{array}{l}\text { all (created, existing, relocating) } \\
\text { with up to 50 employees }\end{array}$ \\
\hline Exemption & $100 \%$ during 2 years & $100 \%$ during 5 years \\
\hline
\end{tabular}

Local property tax exemption

\begin{tabular}{l|l|l}
\hline Eligibility & None & all (created, existing, relocating) \\
\hline Exemption & & $100 \%$ during 5 years \\
\hline
\end{tabular}

Source: Legislative texts (Journal officiel, 1995). 
Table 2: Average socio-economic indicators of the urban areas

\begin{tabular}{|c|c|c|c|c|}
\hline & \multirow[t]{2}{*}{$\mathbf{E Z}$} & \multicolumn{2}{|c|}{ ZRU } & \multirow[t]{2}{*}{ ZUS } \\
\hline & & $>10,000$ pop & $<10,000$ pop & \\
\hline Number of zones & 45 & 69 & 282 & 321 \\
\hline Unemployment rate & 21.9 & 18.2 & 24.3 & 17.9 \\
\hline Percentage of social housing & 64.4 & 63.7 & 66.0 & 61.1 \\
\hline Percentage of foreign people & 21.8 & 16.3 & 20.0 & 17.2 \\
\hline Percentage of unskilled people & 43.1 & 36.4 & 45.8 & 37.9 \\
\hline $\begin{array}{l}\text { Percentage of young people } \\
\text { (aged under 25) }\end{array}$ & 46.7 & 43.2 & 45.5 & 41.2 \\
\hline $\begin{array}{l}\text { Average potential tax revenue } \\
\text { (in euros) }\end{array}$ & 2,707 & 3,212 & 2,609 & 3,438 \\
\hline
\end{tabular}

Table 3: Logit regressions for propensity score estimation

\begin{tabular}{lcc}
\hline & Area selected & More than 10,000 \\
& $(1)$ & $(2)$ \\
& $-17.09^{* *}$ & $-8.40^{* * *}$ \\
as Enterprise Zone & $(7.73)$ & $(3.20)$ \\
intercept & -12.78 & $54.28^{* * *}$ \\
Pct. of executives & $(43.33)$ & $(17.87)$ \\
Pct. of stable households & -1.69 & $0.89^{*}$ \\
& $(1.06)$ & $(0.47)$ \\
Unemployment rate & $13.24^{*}$ & -2.24 \\
& $(7.38)$ & $(2.76)$ \\
Pct. of young people & $16.22^{*}$ & 4.99 \\
& $(8.90$ & $(3.26)$ \\
Pct. of social housing & $-3.45^{*}$ & -0.85 \\
Potential tax revenue & $(2.06)$ & $(0.73)$ \\
& $-0.001^{* * *}$ & $0.0003^{* *}$ \\
Pct. of foreigners & $(0.0003)$ & $(0.0001)$ \\
& $14.22^{* * *}$ & -0.62 \\
Pct. of unskilled people & $(5.45)$ & $(1.87)$ \\
& $61.86^{* *}$ & $22.36^{*}$ \\
Pct. of unskilled people & $(27.53)$ & $(12.05)$ \\
& $-78.58^{* *}$ & $-32.10^{* *}$ \\
& $(33.18)$ & $(14.40)$ \\
\hline
\end{tabular}

Notes: The first column corresponds to logit regression of the conditional probability of being selected as EZ, restricted on the areas with more than 10,000 inhabitants. The second column corresponds to the logit regression of the fact of having more than 10,000 inhabitants. Sample size : 395 observations. Confidence intervals at $95 \%$ in brackets. Significance levels: ${ }^{* *} 1 \%,{ }^{* *} 5 \%,{ }^{*} 10 \%$.

Source: Population Census 1990, Insee. 
Table 4: EZ effect on changes in the number of plants compared to 1995 level - robustness tests

\begin{tabular}{|c|c|c|c|c|}
\hline & \multirow{2}{*}{$\begin{array}{c}\text { Propensity score } \\
(1)\end{array}$} & \multicolumn{2}{|c|}{ RDD } & \multirow{2}{*}{$\begin{array}{c}\text { ZRU/ZUS } \\
(4)\end{array}$} \\
\hline & & $(2)$ & $(3)$ & \\
\hline 1995 & $\begin{array}{c}-0.004 \\
{[-0.051,0.042]}\end{array}$ & $\begin{array}{c}-0.066 \\
{[-0.311,0.178]}\end{array}$ & $\begin{array}{c}-0.055 \\
{[-0.179,0.068]}\end{array}$ & $\begin{array}{c}-0.01 \\
{[-0.053,0.033]}\end{array}$ \\
\hline 1996 & $\begin{array}{c}0.031 \\
{[-0.031,0.093]}\end{array}$ & $\begin{array}{c}-0.193 \\
{[-0.519,0.134]}\end{array}$ & $\begin{array}{c}-0.131 \\
{[-0.293,0.032]}\end{array}$ & $\begin{array}{c}-0.013 \\
{[-0.069,0.042]}\end{array}$ \\
\hline 1997 & $\begin{array}{c}0.226^{* * *} \\
{[0.156,0.296]}\end{array}$ & $\begin{array}{c}-0.066 \\
{[-0.438,0.306]}\end{array}$ & $\begin{array}{c}0.038 \\
{[-0.143,0.219]}\end{array}$ & $\begin{array}{c}-0.017 \\
{[-0.078,0.045]}\end{array}$ \\
\hline 1998 & $\begin{array}{c}0.358^{* * *} \\
{[0.275,0.442]}\end{array}$ & $\begin{array}{c}0.186 \\
{[-0.173,0.545]}\end{array}$ & $\begin{array}{c}0.219^{*} \\
{[-0.003,0.442]}\end{array}$ & $\begin{array}{c}-0.009 \\
{[-0.07,0.052]}\end{array}$ \\
\hline 1999 & $\begin{array}{c}0.458^{* * *} \\
{[0.363,0.554]}\end{array}$ & $\begin{array}{c}0.374^{*} \\
{[-0.014,0.761]}\end{array}$ & $\begin{array}{c}0.351^{* *} \\
{[0.06,0.642]}\end{array}$ & $\begin{array}{c}0.004 \\
{[-0.062,0.071]}\end{array}$ \\
\hline 2000 & $\begin{array}{c}0.561^{* * *} \\
{[0.449,0.673]}\end{array}$ & $\begin{array}{c}0.519^{* *} \\
{[0.092,0.946]}\end{array}$ & $\begin{array}{c}0.544^{* * *} \\
{[0.203,0.886]}\end{array}$ & $\begin{array}{c}-0.002 \\
{[-0.074,0.069]}\end{array}$ \\
\hline 2001 & $\begin{array}{c}0.7^{* * *} \\
{[0.58,0.82]}\end{array}$ & $\begin{array}{l}0.906^{* * *} \\
{[0.42,1.392]}\end{array}$ & $\begin{array}{c}0.815^{* * *} \\
{[0.347,1.282]}\end{array}$ & $\begin{array}{c}0.009 \\
{[-0.069,0.086]}\end{array}$ \\
\hline 2002 & $\begin{array}{c}0.682^{* * *} \\
{[0.557,0.808]}\end{array}$ & $\begin{array}{c}0.853^{* * *} \\
{[0.338,1.368]}\end{array}$ & $\begin{array}{c}0.806^{* * *} \\
{[0.331,1.281]}\end{array}$ & $\begin{array}{c}0.004 \\
{[-0.082,0.09]}\end{array}$ \\
\hline 2003 & $\begin{array}{c}0.684^{* * *} \\
{[0.555,0.813]}\end{array}$ & $\begin{array}{c}0.769^{* * *} \\
{[0.223,1.315]}\end{array}$ & $\begin{array}{c}0.785^{* * *} \\
{[0.3,1.27]}\end{array}$ & $\begin{array}{c}-0.031 \\
{[-0.118,0.055]}\end{array}$ \\
\hline 2004 & $\begin{array}{c}0.643^{* * *} \\
{[0.504,0.782]}\end{array}$ & $\begin{array}{c}0.73^{* *} \\
{[0.168,1.293]}\end{array}$ & $\begin{array}{c}0.803^{* * *} \\
{[0.299,1.308]}\end{array}$ & $\begin{array}{c}-0.041 \\
{[-0.131,0.048]}\end{array}$ \\
\hline 2005 & $\begin{array}{c}0.645^{* * *} \\
{[0.503,0.786]}\end{array}$ & $\begin{array}{c}0.816^{* * *} \\
{[0.252,1.38]}\end{array}$ & $\begin{array}{c}0.843^{* * *} \\
{[0.393,1.293]}\end{array}$ & $\begin{array}{c}0.01 \\
{[-0.089,0.109]}\end{array}$ \\
\hline 2006 & $\begin{array}{c}0.596^{* * *} \\
{[0.456,0.735]}\end{array}$ & $\begin{array}{c}0.8^{* * *} \\
{[0.242,1.358]}\end{array}$ & $\begin{array}{c}0.797^{* * *} \\
{[0.248,1.346]}\end{array}$ & $\begin{array}{c}0.02 \\
{[-0.072,0.111]}\end{array}$ \\
\hline $\mathrm{Nb}$ obs. & 395 & 395 & 103 & 667 \\
\hline 1st stage F-stat & & 22.95 & 14.93 & \\
\hline Sample & $\begin{array}{l}\text { all ZRUs } \\
\text { and EZs }\end{array}$ & $\begin{array}{l}\text { all ZRUs } \\
\text { and EZs }\end{array}$ & $\begin{array}{c}\text { ZRUs and EZs } \\
\text { pop. between } \\
7,000 \text { and } 13,000\end{array}$ & $\begin{array}{l}\text { all ZUSs } \\
\text { and ZRUs }\end{array}$ \\
\hline $\begin{array}{l}\text { Control } \\
\text { Variables }\end{array}$ & $\begin{array}{l}\text { Score and } \\
\text { trend var. }\end{array}$ & $\begin{array}{l}\text { Score and } \\
\text { trend var. }\end{array}$ & No & $\begin{array}{l}\text { Score and } \\
\text { trend var. }\end{array}$ \\
\hline
\end{tabular}

Notes: Estimates of the fact of being treated on $\Delta_{1995} \log \left(Y_{i t}\right)$, the difference in log outcomes between year $\mathrm{t}$ and 1995. Column (1) corresponds to the method based on propensity score and subclassification; columns (2) and (3) both correspond to a regression discontinuity design method (respectively regression on the whole sample correcting for dependance on size and 2sls local regression on a small window around the threshold); column (4) corresponds to the estimation of being ZRU by a method based on propensity score and subclassification using the sample of ZUS (excluding EZs) as control group. Confidence intervals at $95 \%$ in brackets. Significance levels: ${ }^{* * *}$ $1 \%,{ }^{* *} 5 \%,{ }^{*} 10 \%$.

Sources: Administrative employer-employee database on wages (DADS) and French business register (SIRENE), Insee. 


\section{A A brief description of the French EZ tax cuts system}

Plants located in EZ as well as plants in ZRU benefit from several tax exemptions, the extent of which varies from EZ to ZRU in terms of the amount concerned and the duration of the relief (see Table 1). The amounts and the eligibility conditions are modified yearly, but the main elements may be summarized as follows :

First, plants located in EZ and ZRU benefit from exemptions for employer payroll taxes (occupational injury, transportation, housing, family benefit and social insurance contributions). Employees with open-ended or fixed-term employment contracts of more than 12 months are exempt from employer payroll taxes, on the fraction of their salary lying beneath 1.5 times the minimum wage (Smic). In 2006, the ceiling was lowered to 1.4 times the minimum wage. Tradesmen and shopkeepers benefit from a total exemption from health insurance contributions until the salary reaches a level of 1.5 times minimum wage. The duration of this exemption is only one year in ZRU, while in EZ it comes from 5 years of completed exemption completed by decreasing exemption. Besides, the exemptions concern only new hires in ZRU while they benefit all salaried workers in EZ, conditional upon the fact that the plant hired $20 \%$ of its labor force locally ("clause d'embauche locale"). This condition was not applied in practice in the first years of the EZ, so in December 2000 a new law reinforced the firms' obligations in this respect (a specific declaration is required to benefit from tax cuts, and their amounts were reduced for transferred jobs). In December 2002, the needed proportion of local hiring was increased from $20 \%$ to $33 \%$.

All plants in EZ benefit from a full exemption from corporate income tax for five years starting from the date they locate in the zone. However, this tax cut is restricted to profit below a certain amount, which implies a maximum gain limited to around 20,000 euros per year. In ZRU the exemption is limited to newly created plants in the area, which benefit from full exemption for 2 years and decreasing exemption for the next 3 .

All plants in EZ with less than 50 employees on 1 January 1997 (or at the time of the first location in the EZ) also benefit from a full exemption from local business tax for five years. In ZRU the exemption concerns plants with less than 150 employees at the current date. This exemption is limited, however, and in EZ the ceiling is much higher than in ZRU: FF3,000,000 (around 460,000 euros) per year in 2001 while it was only FF920,000 (around 139,000 euros) per year for companies created after 1997 in ZRU (and FF410,000 - around 62,000 euros- for companies present prior this date).

Finally, all buildings located in EZ belonging to plants liable for the property tax on buildings are exempt for 5 years. No such exemption exists in ZRU. Companies in EZ also benefit from additional exemptions on specific taxes, such as the tax on property transfer for shops (to a maximum FF700,000, i.e. around 107,000 euros), fees for the creation of new office buildings in Ile-de-France (Paris metropolitan region), or total 
exemption from local land tax for 5 years. 


\section{B A simulation of the amount of tax cuts at the firm level}

In order to assess the magnitude of the incentives at the firm level, we use the individual tax returns database prior to the implementation of the program, and simulate tax cuts using the precise program tax cuts scheme. More specifically, we apply the precise scheme of the EZ program, as described in Table 1, to the distribution of wages and sales in the firm observed in 1995 and compared it to the common tax scheme that applied to all French firms. Using the year 1995 also allows us to avoid having to reckon with any potential changes in the financial structure or wage distribution due to the implementation of EZs. We perform the simulation on all French firms with less than fifty employees, meaning those eligible for the EZ program.

The main components are payroll and corporate income tax exemptions. For the former, we use the DADS database that provides gross wages for each employee. We thus apply both national and EZ payroll tax rates at the worker level, and consolidate these data to simulate the gain a firm derives from locating in EZ (see Table B.1). The national payroll tax rates have sharply decreased since 2003 (loi Fillon) for the lowest wages (Figure B.1), and this change may have reduced the attractiveness of the EZ somewhat. We thus apply both the tax scheme prevailing in 1997, and the one in force after the implementation of the loi Fillon. For corporate income tax exemptions, we observe the precise amount of corporate income tax paid by firms in 1995. At this date, most of the small firms were not paying corporate income tax (for instance because their yearly sales were too low). So instead of an average amount, we provide the proportion of these firms (meaning those for whom the exemption from tax cuts is not expected to have a direct incentive effect) as well as the median of the corporate income tax paid, conditionally upon having paid a strictly positive amount (see Table B.2). 
Table B.1: Simulation of labor cost in French small firms and EZ payroll tax cuts, 1997 and 2005 tax schemes. (thousand of euros)

\begin{tabular}{lcccc}
\hline & $\begin{array}{c}\text { 1997 payroll tax scheme } \\
\text { Labor cost } \\
\text { (national } \\
\text { rate) }\end{array}$ & $\begin{array}{c}\text { EZ payroll } \\
\text { tax cuts }\end{array}$ & $\begin{array}{c}\text { Labor cost } \\
\text { (national } \\
\text { rate) }\end{array}$ & $\begin{array}{c}\text { EZ payroll } \\
\text { tax cuts }\end{array}$ \\
\hline Total & 40.4 & 5.9 & 38.3 & 4.5 \\
\hline Food industry & 37.7 & 6 & 35.1 & 3.8 \\
Final good industry & 68.2 & 9.5 & 65.7 & 7.7 \\
Car industry & 148.5 & 22.1 & 145.8 & 18.6 \\
Capital good industry & 111.8 & 15.8 & 109.2 & 13.5 \\
Intermediate good industry & 136.0 & 19.2 & 131.8 & 15.5 \\
Construction & 44.6 & 7.3 & 42.3 & 4.9 \\
Energy & 63.6 & 9.1 & 63.1 & 8.5 \\
Trade & 44.6 & 6.6 & 42.5 & 4.7 \\
Transportation & 70.5 & 10.6 & 67.8 & 8.4 \\
Finance & 42.4 & 5.8 & 41.3 & 4.7 \\
Real estate & 19.4 & 2.9 & 18.1 & 1.8 \\
Business services & 60.0 & 7.7 & 58.5 & 6 \\
Household services & 23.1 & 3.6 & 21.1 & 1.7 \\
Health, education, community work & 23.5 & 3.8 & 21.9 & 1.8 \\
\hline
\end{tabular}

Reading note: Using 1997 tax schemes (respectively 2005 tax scheme), the estimated median labor cost in French small companies is 40.4 thousand of euros (resp. 38.3). The estimated median payroll tax cuts for being in EZ is 5.9 thousand of euros (resp. 4.5).

Source: Administrative employer-employee database on wages (DADS) 1995, restriction to small plants eligible (less than 50 employees), Insee. 
Table B.2: Summary statistics on corporate income tax (1995)

\begin{tabular}{lcc}
\hline Total & $\begin{array}{c}\text { Share of non-taxed } \\
\text { firms }(\%)\end{array}$ & $\begin{array}{c}\text { Median tax paid (for } \\
\text { taxed firms - } \\
\text { thousand of euros) }\end{array}$ \\
\hline Food industry & 76.2 & 3.7 \\
Final good industry & 84.9 & 3.8 \\
Car industry & 68.5 & 3.5 \\
Capital good industry & 52.0 & 6.1 \\
Intermediate good industry & 62.5 & 5.5 \\
Construction & 55.1 & 7.2 \\
Energy & 83.7 & 3.2 \\
Trade & 58.9 & 7.5 \\
Transportation & 73.9 & 3.8 \\
Finance & 79.5 & 4.1 \\
Real estate & 51.7 & 8.2 \\
Business services & 83.0 & 2.6 \\
Household services & 60.5 & 3.8 \\
Health, education, community work & 85.4 & 2.0 \\
\hline
\end{tabular}

Reading note: for all French firms present in 1995, we estimate the proportion that did not pay any corporate income tax and estimate the median corporate income tax paid for those having a strict positive corporate income tax.

Sources: Fiscal database (BRN-RSI) 1995, Insee. 


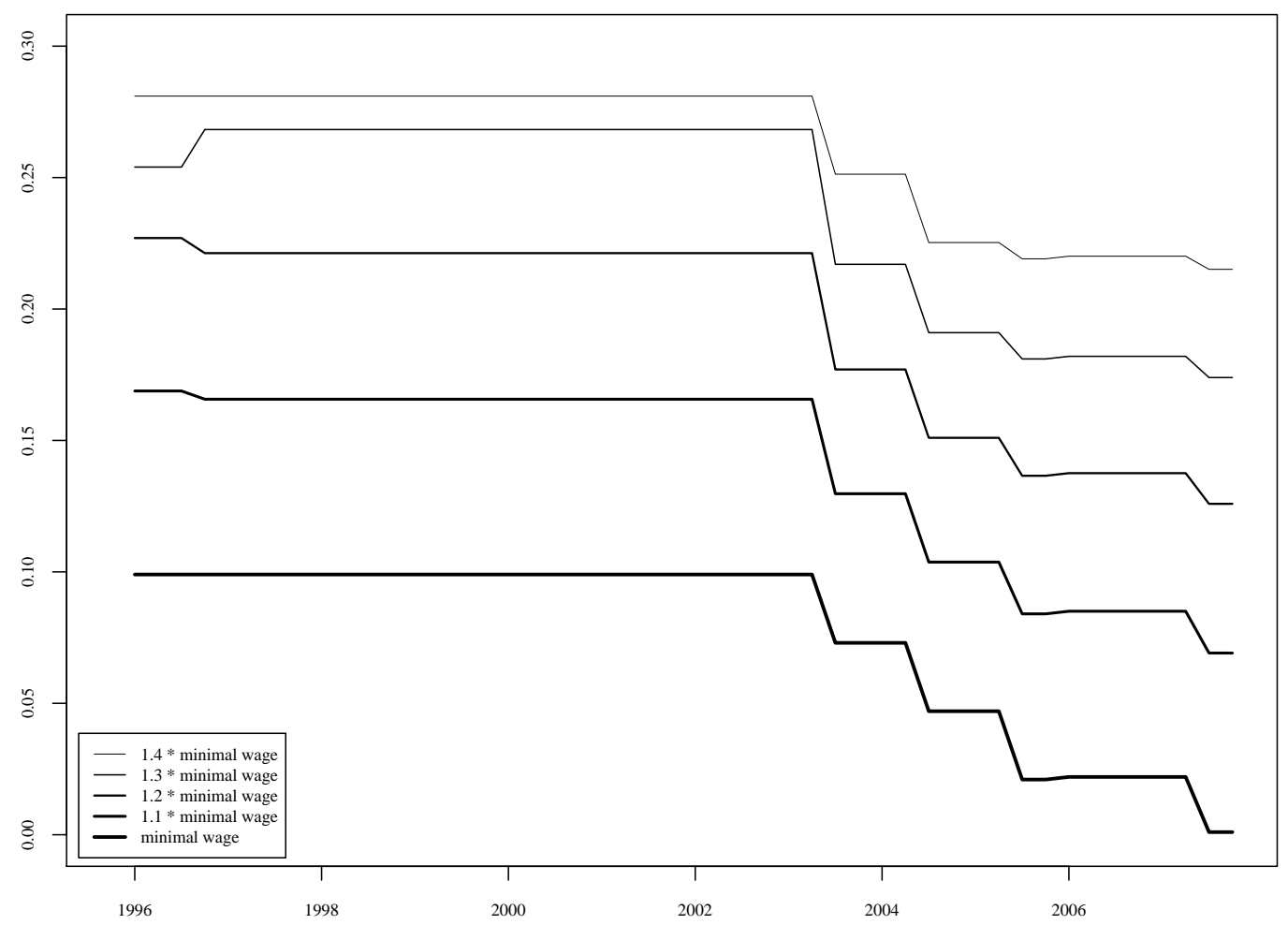

Figure B.1: Gap between national payroll tax rate and EZ payroll tax rate according to earning level. 


\section{Database construction}

Two administrative database from INSEE have been merged. The DADS database provides yearly employment for each company. The SIRENE database follows all French firms. It contents several files which provides the stock of companies on January 1st, each year, as well as firm relocation (the number of new firms created from the 1st of January to the 31st of December of each year). Each company is identified by a registration number. In case of relocation of the company, this registration number changes (in this case, the file corresponding to the flow of companies relates the new and the old registration number). More important, firms are precisely georeferenced. It is crucial for our study as the enterprise zone boundaries do not correspond to the usual administrative borders. The SIRENE database indicates whether the company is located within these boundaries or not, each year from 1995 to 2007.

As a convention, in the text the year $t$ corresponds at a measure at January 1 st, $t+1$ for data on employment and number of firm (which are stock data), while it corresponds to the year $t$ for data on business creation and relocation (which are flow data). This makes the reading of the results easier, as the EZ effects are expected in 1997 for all data.

The data have been modified for the needs of the study. First, georeferenced creation and relocation data are yearly available over the whole period 1995-2007 while the precise location is missing for some years in the data providing the "stock" of firms recorded on January the 1st of each year. More precisely, the geolocation are not available in this database in 1996, 1998, 2000 and 2001. This information can be extrapolated from others year, however : we indeed have access to the precise identification number of each firm. This identification number change in case of a relocation : the presence of the same identification number in year $t_{1}$ and $t_{2}$ means that the firm have not moved over the period. To be more specific, consider the case of 1998 stock data, where all firms are registered, but without precise location. If this very same firm is already registered on database of the previous years, we can use the location variable available in these database. Otherwise, it means that the firm has just located in 1998: in this case we find a record in the database for creation and relocation, that contains a location variable for all years. All in all, geolocation, and more precisely EZ location, can be retrieved for all firms.

Second, the geolocation is not always time-consistent: a company may be registered within an EZ one year and not the other, even if it is located at the exact same address, and even if EZ boundaries are not modified. This is due to some inaccuracies in the GIS. If rare, this missclassification can introduce noise in the estimation. When it is the case, we use, by convention, the first location.

Third, we take into account a subtlety of the enterprise zone boundaries. Recall that enterprise zones are selected among most disadvantaged urban areas (ZUSs). In some 
rare cases, an EZ merges more than one ZUS. As propensity score variables are available at the ZUS scale and the EZ scale, our study unit is the ZUS. That is why our treated group contains 44 areas whereas only 38 EZs where implemented in continental France in 1997. In addition, EZ boundaries and ZUS boundaries may not exactly match. For the sake of consistency, we choose to restrict to companies located within both a ZUS and a ZFU.

Finally, using the DADS database we define a measure of business closure rate. Indeed, as we know precisely the level of employment for each firm and each year, we are able to know when a firm dismisses its last employee. More concretely, a company with employees closes in year $t-1$ if it declares at least one employee on year $t$ and zero employee on year $t+1$. This measure captures potential relocations outside the area as the identification number of the companies changes in this case. This measure is preferred to this provided directly by administrative data on bankruptcies (due to insolvency, i.e. when a company is no longer able to repay its debts), as it is not a reliable measure of discontinuance in business. Not all legal decisions to open bankruptcy proceedings (company filing for bankruptcy as part of legal proceedings) lead to liquidation. Besides, this captures only a little part of discontinuance of business. A plant can, for instance, put a stop to its activity because its owner decides to retire and his assets are not taken over. For the sake of comparison we also define an alternative measure for plant creation. The creation of business with salaried employees corresponds to plants which declare salaried employees for the first time. 


\section{Supplementary Figures}

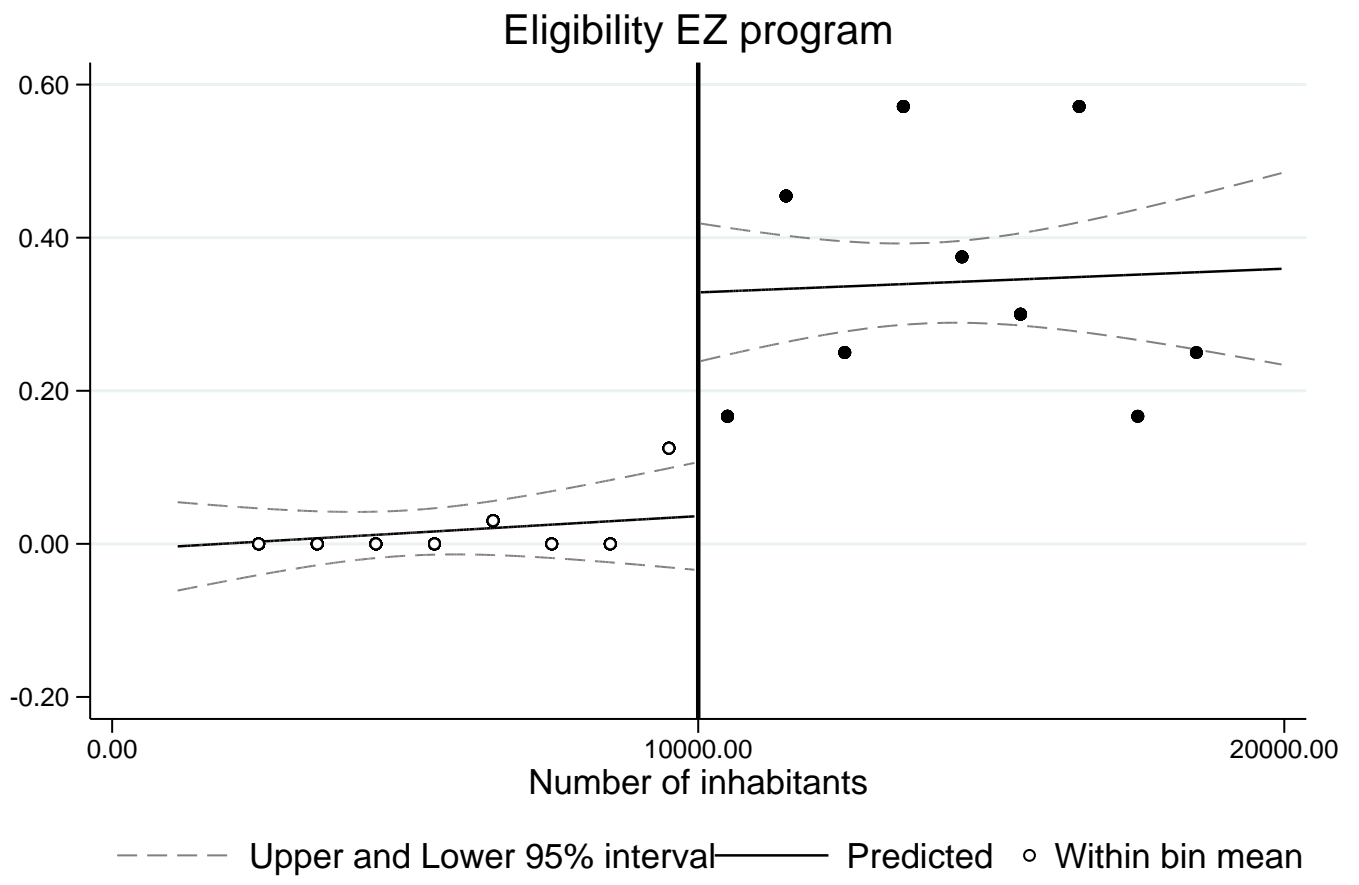

Binsize: 1000, Number of observation: 377

Figure D.1: Share of EZ areas amongst ZRUs as a function of the number of inhabitants 


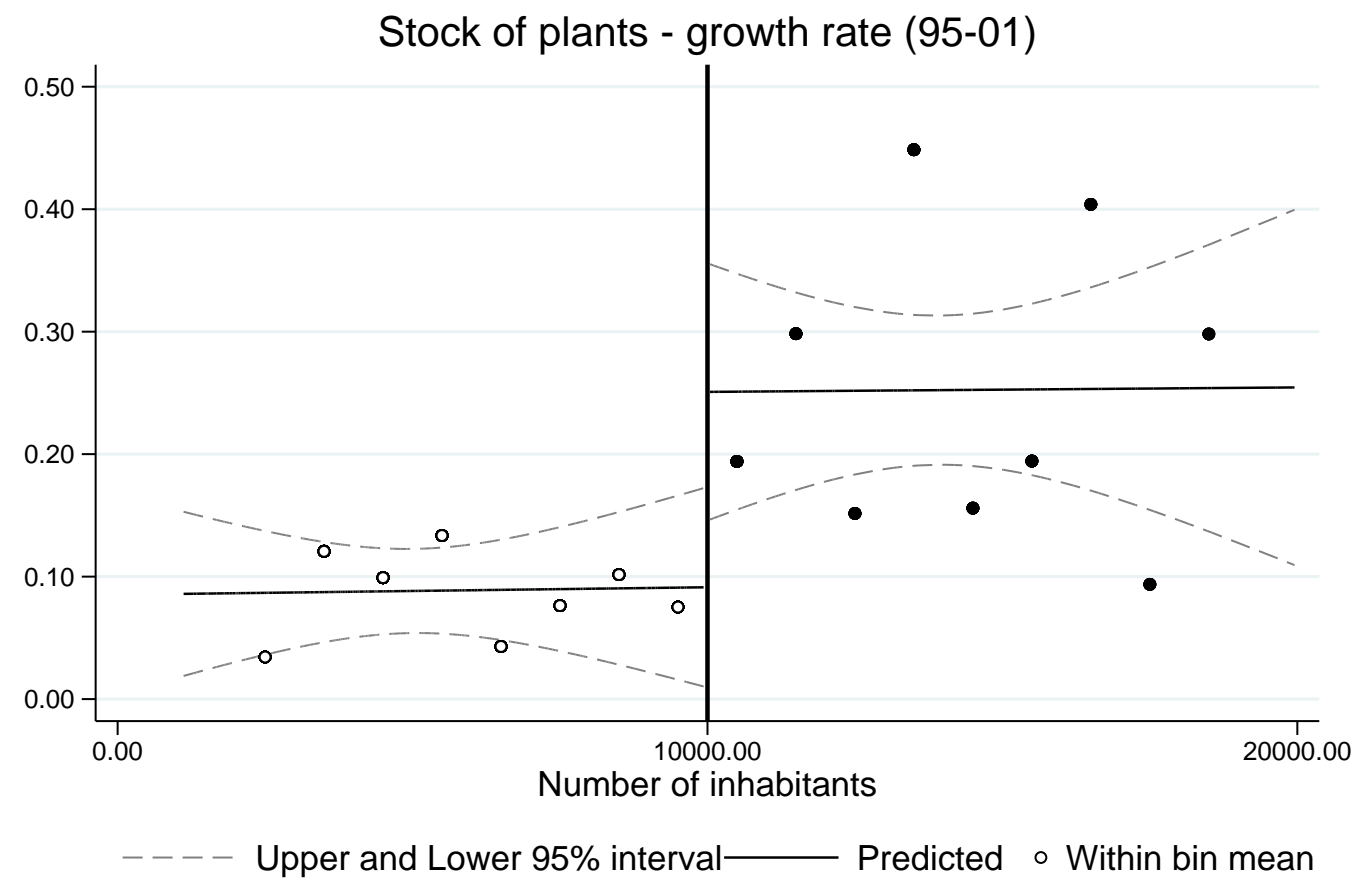

Binsize: 1000, Number of observation: 377

Figure D.2: Stock of plants - grow rate (95-01) - linear fit 


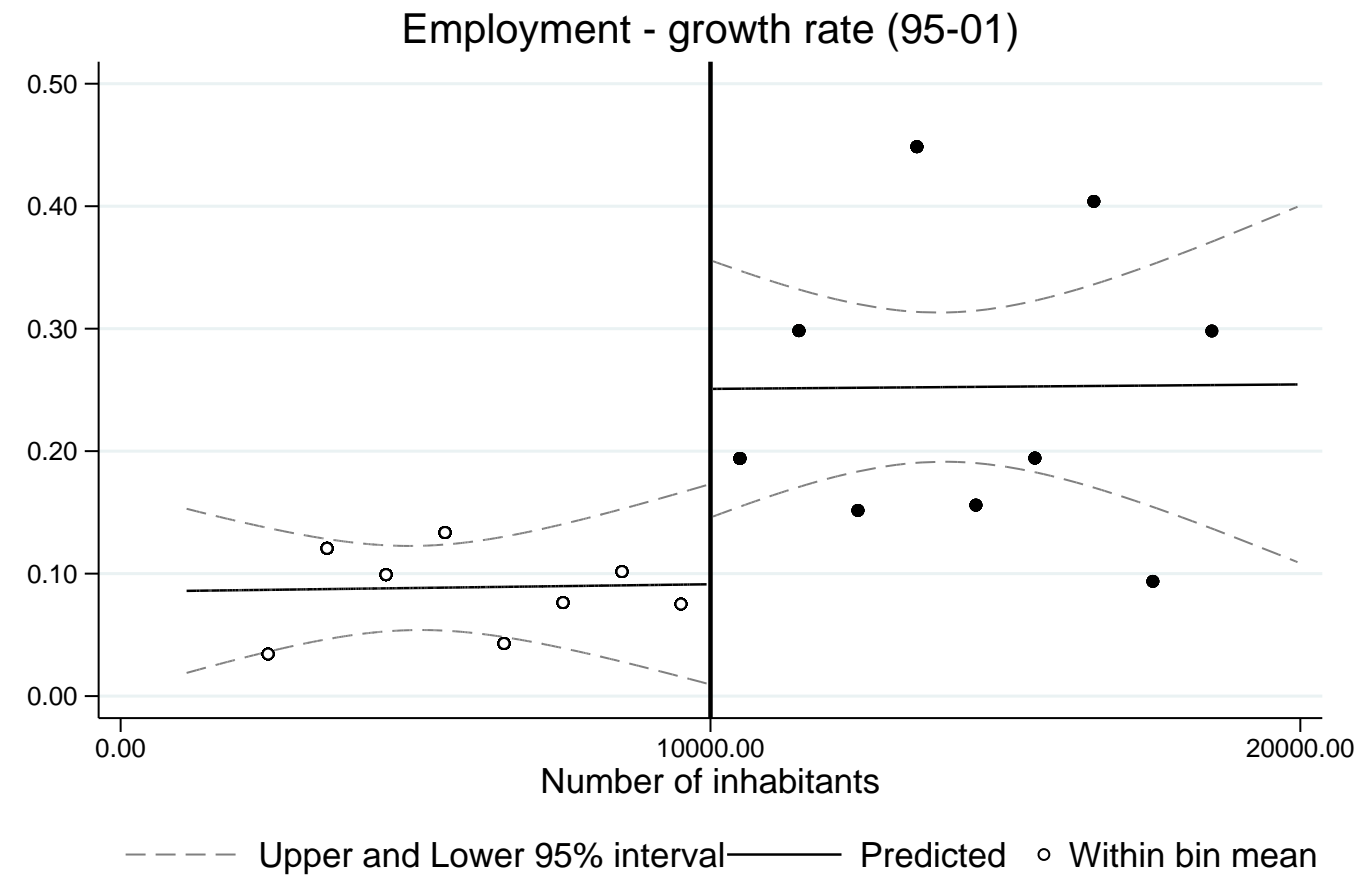

Binsize: 1000, Number of observation: 377

Figure D.3: Employment - grow rate (95-01) - linear fit 


\section{E Detailed results}

Table E.1: EZ effect on changes in flows and stock of plants compared to 1995 level

\begin{tabular}{cccccc}
\hline & $\begin{array}{c}\text { Stock } \\
\text { of plant }\end{array}$ & $\begin{array}{c}\text { Plant } \\
\text { creation }\end{array}$ & $\begin{array}{c}\text { Plant } \\
\text { relocation }\end{array}$ & $\begin{array}{c}\text { New Plant } \\
(\text { DADS })\end{array}$ & $\begin{array}{c}\text { Plant dispa- } \\
\text { rition (DADS) }\end{array}$ \\
\hline 1995 & -0.004 & & & & \\
& {$[-0.051,0.042]$} & & & & \\
1996 & 0.031 & 0.097 & -0.148 & 0.101 & -0.058 \\
& {$[-0.031,0.093]$} & {$[-0.17,0.364]$} & {$[-0.628,0.332]$} & {$[-0.335,0.538]$} & {$[-0.377,0.26]$} \\
1997 & $0.226^{* * *}$ & $0.644^{* * *}$ & $0.919^{* * *}$ & $1.369^{* * *}$ & -0.203 \\
& {$[0.156,0.296]$} & {$[0.399,0.89]$} & {$[0.37,1.468]$} & {$[0.972,1.767]$} & {$[-0.497,0.092]$} \\
1998 & $0.358^{* * *}$ & $0.747^{* * *}$ & $1.216^{* * *}$ & $1.151^{* * *}$ & $0.353^{* *}$ \\
& {$[0.275,0.442]$} & {$[0.49,1.004]$} & {$[0.511,1.921]$} & {$[0.71,1.593]$} & {$[0.059,0.648]$} \\
1999 & $0.458^{* * *}$ & $0.748^{* * *}$ & $1.126^{* * *}$ & $1.016^{* * *}$ & $0.69^{* * *}$ \\
& {$[0.363,0.554]$} & {$[0.473,1.023]$} & {$[0.478,1.775]$} & {$[0.574,1.458]$} & {$[0.395,0.984]$} \\
2000 & $0.561^{* * *}$ & $0.807^{* * *}$ & $1.422^{* * *}$ & $1.243^{* * *}$ & $0.701^{* * *}$ \\
& {$[0.449,0.673]$} & {$[0.549,1.064]$} & {$[0.906,1.937]$} & {$[0.8,1.686]$} & {$[0.364,1.038]$} \\
2001 & $0.7^{* * *}$ & $0.962^{* * *}$ & $1.784^{* * *}$ & $1.361^{* * *}$ & $0.815^{* * *}$ \\
& {$[0.58,0.82]$} & {$[0.683,1.242]$} & {$[1.195,2.373]$} & {$[0.874,1.848]$} & {$[0.53,1.099]$} \\
2002 & $0.682^{* * *}$ & $0.45^{* * *}$ & $0.582^{* *}$ & $0.611^{* *}$ & $1.002^{* * *}$ \\
& {$[0.557,0.808]$} & {$[0.142,0.757]$} & {$[0.024,1.14]$} & {$[0.069,1.15]$} & {$[0.704,1.299]$} \\
2003 & $0.684^{* * *}$ & $0.694^{* * *}$ & $0.737^{* * *}$ & $0.73^{* * *}$ & $0.906^{* * *}$ \\
& {$[0.555,0.813]$} & {$[0.36,1.027]$} & {$[0.196,1.278]$} & {$[0.285,1.176]$} & {$[0.552,1.261]$} \\
2004 & $0.643^{* * *}$ & $0.559^{* * *}$ & $0.882^{* * *}$ & $0.831^{* * *}$ & $1.098^{* * *}$ \\
& {$[0.504,0.782]$} & {$[0.249,0.869]$} & {$[0.234,1.531]$} & {$[0.395,1.267]$} & {$[0.799,1.398]$} \\
2005 & $0.645^{* * *}$ & $0.635^{* * *}$ & $0.703^{* *}$ & $0.746^{* * *}$ & $0.932^{* * *}$ \\
& {$[0.503,0.786]$} & {$[0.372,0.899]$} & {$[0.126,1.28]$} & {$[0.291,1.2]$} & {$[0.618,1.245]$} \\
2006 & $0.596^{* * *}$ & $0.607^{* * *}$ & $0.693^{* *}$ & $0.597^{* * *}$ & $0.943^{* * *}$ \\
& {$[0.456,0.735]$} & {$[0.284,0.931]$} & {$[0.076,1.31]$} & {$[0.206,0.988]$} & {$[0.647,1.239]$} \\
2007 & & $0.543^{* * *}$ & $0.755^{* * *}$ & & \\
& & {$[0.288,0.798]$} & {$[0.188,1.322]$} & & \\
\hline
\end{tabular}

Notes: Estimates of the fact of being EZ on $\Delta_{1995} \log \left(Y_{i t}\right)$, the difference in log outcomes between year $t$ and 1995. Estimations based on regression and subclassification (four stratas based on the propensity score) using all covariates in Table 3 and the number of inhabitants in the area. Sample size : 395 observations. Confidence intervals at $95 \%$ in brackets. Significance levels: ${ }^{* *} 1 \%,{ }^{* *} 5 \%,{ }^{*} 10 \%$.

Sources: Administrative employer-employee database on wages (DADS) and French business register (SIRENE), Insee. 
Table E.2: EZ effect on changes in the employment compared to 1995 level

\begin{tabular}{|c|c|c|c|c|c|c|}
\hline & Employment & $\begin{array}{l}\text { Low-skilled } \\
\text { employment }\end{array}$ & $\begin{array}{c}\text { Skilled } \\
\text { employment }\end{array}$ & $\begin{array}{l}\text { High-skilled } \\
\text { employment }\end{array}$ & $\begin{array}{l}\text { Employment } \\
\text { in firms } \\
\text { established } \\
\text { before } 1995\end{array}$ & $\begin{array}{c}\text { Employment } \\
\text { in firms } \\
\text { established } \\
\text { after } 1995\end{array}$ \\
\hline 1995 & $\begin{array}{c}0.011 \\
{[-0.148,0.169]}\end{array}$ & $\begin{array}{c}0.033 \\
{[-0.158,0.224]}\end{array}$ & $\begin{array}{c}0.015 \\
{[-0.159,0.19]}\end{array}$ & $\begin{array}{c}0.019 \\
{[-0.162,0.199]}\end{array}$ & $\begin{array}{c}-0.068 \\
{[-0.176,0.04]}\end{array}$ & \\
\hline 1996 & $\begin{array}{c}0.075 \\
{[-0.129,0.279]}\end{array}$ & $\begin{array}{c}0.144 \\
{[-0.138,0.427]}\end{array}$ & $\begin{array}{c}0.097 \\
{[-0.155,0.35]}\end{array}$ & $\begin{array}{c}-0.012 \\
{[-0.248,0.224]}\end{array}$ & $\begin{array}{c}0.029 \\
{[-0.117,0.175]}\end{array}$ & $\begin{array}{c}-0.06 \\
{[-0.534,0.414]}\end{array}$ \\
\hline 1997 & $\begin{array}{c}0.375^{* * *} \\
{[0.148,0.602]}\end{array}$ & $\begin{array}{c}0.457^{* * *} \\
{[0.173,0.742]}\end{array}$ & $\begin{array}{c}0.454^{* * *} \\
{[0.191,0.716]}\end{array}$ & $\begin{array}{c}0.292^{* *} \\
{[0.021,0.563]}\end{array}$ & $\begin{array}{c}0.065 \\
{[-0.104,0.234]}\end{array}$ & $\begin{array}{c}0.714^{* * *} \\
{[0.197,1.231]}\end{array}$ \\
\hline 1998 & $\begin{array}{c}0.602^{* * *} \\
{[0.358,0.847]}\end{array}$ & $\begin{array}{c}0.602^{* * *} \\
{[0.277,0.927]}\end{array}$ & $\begin{array}{c}0.717^{* * *} \\
{[0.442,0.992]}\end{array}$ & $\begin{array}{c}0.522^{* * *} \\
{[0.235,0.809]}\end{array}$ & $\begin{array}{c}0.107 \\
{[-0.083,0.296]}\end{array}$ & $\begin{array}{c}0.984^{* * *} \\
{[0.456,1.512]}\end{array}$ \\
\hline 1999 & $\begin{array}{c}0.804^{* * *} \\
{[0.527,1.08]}\end{array}$ & $\begin{array}{c}0.903^{* * *} \\
{[0.56,1.246]}\end{array}$ & $\begin{array}{c}0.867^{* * *} \\
{[0.537,1.196]}\end{array}$ & $\begin{array}{c}0.752^{* * *} \\
{[0.458,1.046]}\end{array}$ & $\begin{array}{c}0.077 \\
{[-0.161,0.315]}\end{array}$ & $\begin{array}{c}1.134^{* * *} \\
{[0.604,1.663]}\end{array}$ \\
\hline 2000 & $\begin{array}{c}0.947^{* * *} \\
{[0.65,1.244]}\end{array}$ & $\begin{array}{c}1.06^{* * *} \\
{[0.688,1.431]}\end{array}$ & $\begin{array}{l}1.032^{* * *} \\
{[0.684,1.38]}\end{array}$ & $\begin{array}{c}0.876^{* * *} \\
{[0.567,1.186]}\end{array}$ & $\begin{array}{c}-0.02 \\
{[-0.269,0.229]}\end{array}$ & $\begin{array}{c}1.246^{* * *} \\
{[0.708,1.784]}\end{array}$ \\
\hline 2001 & $\begin{array}{c}1.098^{* * *} \\
{[0.798,1.398]}\end{array}$ & $\begin{array}{c}1.153^{* * *} \\
{[0.753,1.553]}\end{array}$ & $\begin{array}{c}1.13^{* * *} \\
{[0.786,1.475]}\end{array}$ & $\begin{array}{c}1.12^{* * *} \\
{[0.783,1.456]}\end{array}$ & $\begin{array}{c}0.028 \\
{[-0.282,0.338]}\end{array}$ & $\begin{array}{c}1.332^{* * *} \\
{[0.772,1.891]}\end{array}$ \\
\hline 2002 & $\begin{array}{c}1.123^{* * *} \\
{[0.822,1.424]}\end{array}$ & $\begin{array}{c}1.255^{* * * *} \\
{[0.869,1.642]}\end{array}$ & $\begin{array}{c}1.198^{* * *} \\
{[0.851,1.545]}\end{array}$ & $\begin{array}{c}1.054^{* * *} \\
{[0.701,1.406]}\end{array}$ & $\begin{array}{c}0.05 \\
{[-0.272,0.372]}\end{array}$ & $\begin{array}{c}1.328^{* * *} \\
{[0.771,1.884]}\end{array}$ \\
\hline 2003 & $\begin{array}{l}1.114^{* * *} \\
{[0.799,1.43]}\end{array}$ & $\begin{array}{c}1.325^{* * *} \\
{[0.922,1.728]}\end{array}$ & $\begin{array}{c}1.144^{* * *} \\
{[0.766,1.522]}\end{array}$ & $\begin{array}{l}1.067^{* * *} \\
{[0.723,1.41]}\end{array}$ & $\begin{array}{c}0.091 \\
{[-0.264,0.447]}\end{array}$ & $\begin{array}{c}1.273^{* * *} \\
{[0.708,1.839]}\end{array}$ \\
\hline 2004 & $\begin{array}{c}1.076^{* * *} \\
{[0.748,1.403]}\end{array}$ & $\begin{array}{c}1.385^{* * *} \\
{[0.967,1.802]}\end{array}$ & $\begin{array}{c}1.127^{* * *} \\
{[0.732,1.521]}\end{array}$ & $\begin{array}{c}0.911^{* * *} \\
{[0.554,1.268]}\end{array}$ & $\begin{array}{c}0.071 \\
{[-0.292,0.433]}\end{array}$ & $\begin{array}{c}1.219^{* * *} \\
{[0.655,1.783]}\end{array}$ \\
\hline 2005 & $\begin{array}{c}1.067^{* * *} \\
{[0.734,1.399]}\end{array}$ & $\begin{array}{c}1.318^{* * *} \\
{[0.913,1.723]}\end{array}$ & $\begin{array}{c}1.095^{* * *} \\
{[0.675,1.515]}\end{array}$ & $\begin{array}{c}0.988^{* * *} \\
{[0.638,1.337]}\end{array}$ & $\begin{array}{c}0.137 \\
{[-0.227,0.502]}\end{array}$ & $\begin{array}{c}1.148^{* * *} \\
{[0.599,1.698]}\end{array}$ \\
\hline 2006 & $\begin{array}{c}0.926^{* * *} \\
{[0.582,1.269]}\end{array}$ & $\begin{array}{c}1.092^{* * *} \\
{[0.697,1.487]}\end{array}$ & $\begin{array}{c}0.97^{* * *} \\
{[0.576,1.363]}\end{array}$ & $\begin{array}{c}0.892^{* * *} \\
{[0.539,1.246]}\end{array}$ & $\begin{array}{c}0.173 \\
{[-0.211,0.557]}\end{array}$ & $\begin{array}{c}0.866^{* * *} \\
{[0.324,1.408]}\end{array}$ \\
\hline
\end{tabular}

Notes: Estimates of the fact of being EZ on $\Delta_{1995} \log \left(Y_{i t}\right)$, the difference in log outcomes between year $\mathrm{t}$ and 1995 .

Estimations are based on propensity score and subclassification (five strata based on the propensity score) using all covariates in Table 3 and the number of inhabitants in the area. Sample size : 395 observations. Confidence intervals at $95 \%$ in brackets. Significance levels: ${ }^{* * *} 1 \%,{ }^{* *} 5 \%,{ }^{*} 10 \%$.

Sources: Administrative employer-employee database on wages (DADS) and French business register (SIRENE), Insee. 
Table E.3: EZ effect on changes in the resident on non resident employment, compared to 1995 level

\begin{tabular}{cccc}
\hline & Resident & Non Resident & Rate of Resident \\
\hline 1995 & 0.01 & -0.031 & 0.015 \\
& {$[-0.144,0.165]$} & {$[-0.204,0.143]$} & {$[-0.091,0.122]$} \\
1996 & 0.048 & 0.048 & -0.008 \\
& {$[-0.147,0.242]$} & {$[-0.176,0.272]$} & {$[-0.13,0.115]$} \\
1997 & $0.289^{* * *}$ & $0.398^{* * *}$ & -0.059 \\
& {$[0.073,0.505]$} & {$[0.151,0.645]$} & {$[-0.186,0.069]$} \\
1998 & $0.519^{* * *}$ & $0.624^{* * *}$ & -0.065 \\
& {$[0.288,0.749]$} & {$[0.349,0.899]$} & {$[-0.199,0.07]$} \\
1999 & $0.694^{* * *}$ & $0.835^{* * *}$ & -0.084 \\
& {$[0.427,0.961]$} & {$[0.533,1.138]$} & {$[-0.211,0.042]$} \\
2000 & $0.858^{* * *}$ & $0.982^{* * *}$ & -0.07 \\
& {$[0.591,1.126]$} & {$[0.645,1.319]$} & {$[-0.201,0.062]$} \\
2001 & $1.01^{* * *}$ & $1.127^{* * *}$ & -0.057 \\
& {$[0.745,1.274]$} & {$[0.777,1.477]$} & {$[-0.204,0.09]$} \\
2002 & $1.066^{* * *}$ & $1.147^{* * *}$ & -0.047 \\
& {$[0.794,1.339]$} & {$[0.801,1.494]$} & {$[-0.199,0.104]$} \\
2003 & $1.065^{* * *}$ & $1.129^{* * *}$ & -0.032 \\
& {$[0.78,1.35]$} & {$[0.772,1.485]$} & {$[-0.182,0.119]$} \\
2004 & $1.033^{* * *}$ & $1.11^{* * *}$ & -0.025 \\
& {$[0.731,1.335]$} & {$[0.745,1.474]$} & {$[-0.174,0.124]$} \\
2005 & $0.994^{* * *}$ & $1.106^{* * *}$ & -0.061 \\
& {$[0.683,1.305]$} & {$[0.736,1.477]$} & {$[-0.219,0.097]$} \\
2006 & $0.839^{* * *}$ & $0.984^{* * *}$ & -0.071 \\
& {$[0.515,1.163]$} & {$[0.618,1.35]$} & {$[-0.229,0.088]$} \\
\hline
\end{tabular}

Note : Estimates of the fact of being EZ on $\Delta_{1995} \log \left(Y_{i t}\right)$, the difference in log outcomes between year $t$ and 1995. Estimations are based on propensity score and subclassification (four strata based on the propensity score) and using all covariates in Table 3 and the number of inhabitants in the area. Sample size : 395 observations. Confidence intervals at $95 \%$ in brackets. Significance levels: ${ }^{* * *} 1 \%,{ }^{* *} 5 \%,{ }^{*} 10 \%$.

Sources: Administrative employer-employee database on wages (DADS) and French business register (SIRENE), Insee. 
Table E.4: EZ effect on changes in the number of plants compared to 1995 level by sector of activity

\begin{tabular}{|c|c|c|c|c|c|}
\hline & $\begin{array}{c}\text { Business } \\
\text { services }\end{array}$ & Trade & $\begin{array}{c}\text { Health, } \\
\text { education, } \\
\text { community } \\
\text { work }\end{array}$ & Construction & Manufacturing \\
\hline 1995 & $\begin{array}{c}-0.029 \\
{[-0.187,0.128]}\end{array}$ & $\begin{array}{c}-0.026 \\
{[-0.096,0.044]}\end{array}$ & $\begin{array}{c}-0.003 \\
{[-0.061,0.056]}\end{array}$ & $\begin{array}{c}0.008 \\
{[-0.119,0.134]}\end{array}$ & $\begin{array}{c}0.01 \\
{[-0.109,0.129]}\end{array}$ \\
\hline 1996 & $\begin{array}{c}0.072 \\
{[-0.133,0.277]}\end{array}$ & $\begin{array}{c}0.024 \\
{[-0.07,0.119]}\end{array}$ & $\begin{array}{c}-0.028 \\
{[-0.125,0.069]}\end{array}$ & $\begin{array}{c}-0.02 \\
{[-0.205,0.165]}\end{array}$ & $\begin{array}{c}0.068 \\
{[-0.1,0.236]}\end{array}$ \\
\hline 1997 & $\begin{array}{c}0.555^{* * *} \\
{[0.332,0.779]}\end{array}$ & $\begin{array}{c}0.174^{* * *} \\
{[0.064,0.283]}\end{array}$ & $\begin{array}{c}0.038 \\
{[-0.092,0.168]}\end{array}$ & $\begin{array}{c}0.271^{* * *} \\
{[0.067,0.476]}\end{array}$ & $\begin{array}{c}0.253^{* *} \\
{[0.054,0.453]}\end{array}$ \\
\hline 1998 & $\begin{array}{c}0.895^{* * *} \\
{[0.628,1.162]}\end{array}$ & $\begin{array}{c}0.221^{* * *} \\
{[0.099,0.342]}\end{array}$ & $\begin{array}{c}0.154^{*} \\
{[-0.007,0.316]}\end{array}$ & $\begin{array}{c}0.502^{* * *} \\
{[0.288,0.715]}\end{array}$ & $\begin{array}{c}0.439^{* * *} \\
{[0.225,0.652]}\end{array}$ \\
\hline 1999 & $\begin{array}{c}1.031^{* * *} \\
{[0.768,1.293]}\end{array}$ & $\begin{array}{c}0.296^{* * *} \\
{[0.156,0.435]}\end{array}$ & $\begin{array}{c}0.228^{* *} \\
{[0.044,0.412]}\end{array}$ & $\begin{array}{c}0.643^{* * *} \\
{[0.412,0.874]}\end{array}$ & $\begin{array}{c}0.462^{* * *} \\
{[0.218,0.706]}\end{array}$ \\
\hline 2000 & $\begin{array}{c}1.235^{* * *} \\
{[0.953,1.517]}\end{array}$ & $\begin{array}{c}0.355^{* * *} \\
{[0.208,0.502]}\end{array}$ & $\begin{array}{c}0.273^{* * *} \\
{[0.081,0.465]}\end{array}$ & $\begin{array}{c}0.737^{* * *} \\
{[0.473,1.001]}\end{array}$ & $\begin{array}{c}0.626^{* * *} \\
{[0.359,0.893]}\end{array}$ \\
\hline 2001 & $\begin{array}{c}1.529^{* * *} \\
{[1.24,1.817]}\end{array}$ & $\begin{array}{c}0.435^{* * *} \\
{[0.282,0.588]}\end{array}$ & $\begin{array}{c}0.402^{* * *} \\
{[0.206,0.598]}\end{array}$ & $\begin{array}{c}0.833^{* * *} \\
{[0.554,1.112]}\end{array}$ & $\begin{array}{c}0.732^{* * *} \\
{[0.442,1.022]}\end{array}$ \\
\hline 2002 & $\begin{array}{c}1.46^{* * *} \\
{[1.183,1.737]}\end{array}$ & $\begin{array}{c}0.417^{* * *} \\
{[0.253,0.581]}\end{array}$ & $\begin{array}{c}0.402^{* * *} \\
{[0.189,0.614]}\end{array}$ & $\begin{array}{c}0.869^{* * *} \\
{[0.584,1.154]}\end{array}$ & $\begin{array}{c}0.78^{* * *} \\
{[0.508,1.053]}\end{array}$ \\
\hline 2003 & $\begin{array}{c}1.362^{* * *} \\
{[1.082,1.642]}\end{array}$ & $\begin{array}{c}0.432^{* * *} \\
{[0.262,0.602]}\end{array}$ & $\begin{array}{c}0.426^{* * *} \\
{[0.213,0.64]}\end{array}$ & $\begin{array}{c}0.771^{* * *} \\
{[0.489,1.053]}\end{array}$ & $\begin{array}{c}0.855^{* * *} \\
{[0.588,1.123]}\end{array}$ \\
\hline 2004 & $\begin{array}{c}1.253^{* * *} \\
{[0.967,1.539]}\end{array}$ & $\begin{array}{l}0.387^{* * *} \\
{[0.204,0.57]}\end{array}$ & $\begin{array}{l}0.387^{* * *} \\
{[0.175,0.6]}\end{array}$ & $\begin{array}{c}0.684^{* * *} \\
{[0.387,0.981]}\end{array}$ & $\begin{array}{c}0.899^{* * *} \\
{[0.63,1.167]}\end{array}$ \\
\hline 2005 & $\begin{array}{c}1.274^{* * *} \\
{[0.975,1.573]}\end{array}$ & $\begin{array}{c}0.401^{* * *} \\
{[0.226,0.577]}\end{array}$ & $\begin{array}{c}0.416^{* * *} \\
{[0.206,0.626]}\end{array}$ & $\begin{array}{c}0.678^{* * *} \\
{[0.38,0.976]}\end{array}$ & $\begin{array}{c}0.862^{* * *} \\
{[0.58,1.145]}\end{array}$ \\
\hline 2006 & $\begin{array}{c}1.146^{* * *} \\
{[0.839,1.454]}\end{array}$ & $\begin{array}{c}0.366^{* * *} \\
{[0.195,0.536]}\end{array}$ & $\begin{array}{c}0.465^{* * *} \\
{[0.244,0.686]}\end{array}$ & $\begin{array}{c}0.655^{* * *} \\
{[0.362,0.948]}\end{array}$ & $\begin{array}{c}0.849^{* * *} \\
{[0.57,1.128]}\end{array}$ \\
\hline
\end{tabular}

Notes: Estimate of the fact of being EZ on $\Delta_{1995} \log \left(Y_{i t}\right)$, the difference in log outcomes between year $\mathrm{t}$ and 1995. Estimations based on propensity score and subclassification (four strata based on the propensity score) and using all covariates in Table 3 and the number of inhabitants in the area. Sample size : 395 observations. Confidence intervals at $95 \%$ in brackets. Significance levels: ${ }^{* * *} 1 \%,{ }^{* *} 5 \%,{ }^{*} 10 \%$.

Sources: Administrative employer-employee database on wages (DADS) and French business register (SIRENE), Insee. 